\title{
THE ILLUSION OF "OFFER TO SELL" PATENT INFRINGEMENT: WHEN AN OFFER IS AN OFFER BUT IS NOT AN OFFER
}

\author{
LARRY S. ZELSON ${ }^{\dagger}$
}

INTRODUCTION 1283

I. Evaluating Specific Personal Jurisdiction in "OFFER TO SELL" PATENT INFRINGEMENT CASES.

A. The Federal Circuit Test for Personal Jurisdiction in Patent Cases.. 1290

B. The Federal Circuit's Application of the Akro Test to "Offer to Sell" Patent Infringement Cases. 1294

II. INTERPRETING "OFFER TO SELL" INFRINGEMENT IN THE CONTEXT OF THE PATENT STATUTES AND CONTRACT LAW

A. The Addition of "Offer To Sell" as an Independent Statutory Grant to the Patentee.

B. Distinguishing "Offer To Sell" (Infringement) from "Offer" (Contract Law) and "On Sale" (Patentability Bar)

C. The Federal Circuit's Interpretation of "Offer To Sell" .1306

III. KEEPING THE SUbSTANTIVE "OFFER TO SELL" INFRINGEMENT ANALYSIS DISTINCT FROM THE PERSONAL JURISDICTION DETERMINATION.

A. Mixed Decisions in the District Courts 1312

B. Effective "Offer to Sell" Infringement Liability Requires a Different Analysis

C. A Possible Solution 1319

CONCLUSION 1321

\section{INTRODUCTION}

The approval of the Agreement on Trade-Related Aspects of International Property Rights ${ }^{1}$ (TRIPs) by the United States in 1994 ne-

\footnotetext{
${ }^{\dagger}$ B.S. 1986, Carnegie-Mellon University; M.S. 1989, Stanford University; Engineer 1994, Stanford University; J.D. Candidate 2006, University of Pennsylvania. Thanks to my wife Carolyn for her patience and support. Any errors and all opinions are mine.

${ }^{1}$ Agreement on Trade-Related Aspects of Intellectual Property Rights art. 28, Apr. 15, 1994, Annex 1C, 33 I.L.M. 1197 [hereinafter TRIPs] (expanding the patent grant to include an exclusive right to offer the invention for sale).
} 
cessitated substantial changes to the U.S. patent laws. ${ }^{2}$ In particular, a patentee's grant was expanded to encompass the right to exclude others from offering the patented invention for sale. ${ }^{3}$ Accordingly, 35 U.S.C. $\S 271(\mathrm{a})$, the default provision of the patent infringement statute, was modified to read, in pertinent part, that "whoever without authority makes, uses, offers to sell, or sells any patented invention within the United States ... during the term of the patent therefor, infringes the patent." ${ }^{4}$

Since the addition of "offer to sell" infringement, many cases implicating this statutory provision have been filed in federal district court, ${ }^{5}$ and a few have reached the Court of Appeals for the Federal Circuit (hereinafter Federal Circuit or CAFC). ${ }^{6}$ However, no such

\footnotetext{
${ }^{2}$ See Uruguay Round Agreements Act, Pub. L. No. 103-465, 108 Stat. 4809 (1994) (codified as amended in scattered sections of U.S.C.) [hereinafter URAA] ("An Act to approve and implement the trade agreements concluded in the Uruguay Round of multilateral trade negotiations."). The URAA modified sections of the United States Code too numerous to list comprehensively, including provisions of Titles 7 (agriculture), 15 (commerce and trade), 17 (copyrights), 19 (customs duties), 26 (internal revenue code), 28 (judiciary and judicial procedure), and 35 (patents). Among the many sections of Title 35 amended to bring U.S. patent law into conformity with the requirements of TRIPs, sections 154 (contents and term of patent; provisional rights) and 271 (infringement of patent) are most pertinent to the discussion herein. See URAA, supra, $\S 533,108$ Stat. at 4988 . The changes enacted under the URAA became effective on January 1, 1996, one year after the WTO Agreement entered into force with respect to the United States. Id. § 534, 108 Stat. at 4990. The WTO Agreement entered into force with respect to the United States on January 1, 1995. Proclamation 6780, 60 Fed. Reg. 15,845 (Mar. 27, 1995).

${ }^{3}$ Previously, a patentee only had the right to exclude others from making, using, and selling the invention in the United States, and importing the invention into the United States. 35 U.S.C. \$ 154(a) (1) (1988) (amended 1994).

${ }^{4} 35$ U.S.C. $\$ 271$ (a) (2000) (emphasis added). Section 271 (c) was amended to include "offers to sell" a "component of a patented machine, manufacture, combination, or composition, or a material or apparatus for use in practicing a patented process [if] especially made or especially adapted for use in an infringement of such patent," and $\S 271(\mathrm{~g})$ was amended to include "offers to sell" a "product which is made by" a patented process.

5 See infra notes 8-9 (listing cases involving "offer to sell" infringement).

${ }^{6}$ See, e.g., Fieldturf Int'l, Inc. v. Sprinturf, Inc., 433 F.3d 1366, 1369-70 (Fed. Cir. 2006) (holding that a bid to supply a patented product specified in a Request for Proposal (RFP) is not an infringing "offer to sell" when state law interprets such an RFP to include an "or equal" clause and it is understood that the bidder will be supplying a noninfringing substitute); MEMC Elec. Materials, Inc. v. Mitsubishi Materials Silicon Corp., 420 F.3d 1369, 1379 (Fed. Cir. 2005) (determining that email communications describing an allegedly infringing device, but without including price terms, did not constitute an "offer to sell"); Rotec Indus., Inc. v. Mitsubishi Corp., 215 F.3d 1246, 1254-55 (Fed. Cir. 2000) (analogizing "offer to sell" under $\$ 271$ (a) to the "on sale" bar of 35 U.S.C. $\S 102$ (b) and defining "offer to sell" liability "according to the norms of traditional contractual analysis”); HollyAnne Corp. v. TFT, Inc., 199 F.3d 1304, 1309 (Fed. Cir. 1999) (holding that a "mere offer to donate, where a donation is never
} 
case has yet substantively adjudicated, based on a fully developed record, whether the article or method purportedly offered for sale in fact infringed valid claims of an issued U.S. patent. ${ }^{7}$ Rather, each such reported or unreported case alleging "offer to sell" infringement has received only a preliminary disposition. Most often, these cases have considered either a summary judgment motion based on whether there was an "offer to sell" within the meaning of $\S 271(\mathrm{a})^{8}$ or a mo-

made, cannot be an offer for sale”); 3D Sys., Inc. v. Aarotech Labs., Inc., 160 F.3d 1373, 1379 (Fed. Cir. 1998) (holding that a letter conveying "a description of the allegedly infringing merchandise and the price at which it can be purchased" is an "offer to sell”).

Were an "offer to sell" case to reach trial on all the substantive issues, a claim construction would be required, likely by way of a "Markman" hearing (named after Markman v. Westview Instruments, Inc., 517 U.S. 370 (1996)), with regard to an article that may not yet have been actually made. See William F. Lee \& Anita K. Krug, Still Adjusting to Markman: A Prescription for the Timing of Claim Construction Hearings, 13 HARV. J.L. \& TECH. 55, 56-67 (1999), and Andrew T. Zidel, Patent Claim Construction in the Trial Courts: A Study Showing the Need for Clear Guidance From the Federal Circuit, 33 SETON HALL L. REV. 711, 728-37 (2003), for background on "Markman" hearings.

Additionally, because "offer to sell" cases begin further removed from the ultimate question of infringement of specific patent claims than cases concerning actual making, selling, or use, "offer to sell" cases are less likely to reach a substantive infringement determination. Therefore, perhaps a claim of "offer to sell" infringement is best viewed as a procedural tool for obtaining settlement or for pressuring an alleged prospective infringer to license the invention or to cease and desist from practicing it, rather than as a cause of action for which equitable relief would normally be awarded.

${ }^{8}$ See, e.g., Mahurkar v. C.R. Bard, Inc., No. 01 C 8452, 2003 U.S. Dist. LEXIS 2329, at *21 (N.D. Ill. Feb. 13, 2003) (surmising, based on Rotec and HollyAnne, that for an advertisement to constitute an "offer to sell," it must at least include detailed product information and pricing, but denying defendant's motion for partial summary judgment on other grounds); Star Scientific Inc. v. R.J. Reynolds Tobacco Co., 174 F. Supp. 2d 388, 393-94, 397 (D. Md. 2001) (denying summary judgment after examining the "offer to sell" language of $\S 271(\mathrm{a})$, (c), and (g), and determining that contracting to buy a product made using a patented process, even if the product is not made during the time period in question, is sufficient for purposes of subject matter jurisdiction under FED. R. CIV. P. 12(b) (1)); Cybiotronics, Ltd. v. Golden Source Elecs., Ltd., 130 F. Supp. 2d 1152, 1171, 1777 (C.D. Cal. 2001) (granting the defendant's motion for summary judgment on issues of direct and indirect infringement and holding that infringement cannot "be found solely premised on an 'offer to sell' within the United States, unless the sale that is contemplated by the 'offer' is or will also be consummated within the United States”); Halmar Robicon Group Inc. v. Toshiba Int'l Corp., No. 98501, 1999 U.S. Dist. LEXIS 19869, at*7 (W.D. Pa. Nov. 17, 1999) (denying the plaintiff's motion for summary judgment, despite holding as a matter of law that an "offer to sell" occurred within the United States, because a claim construction was required to determine infringement); Quality Tubing, Inc. v. Precision Tube Holdings Corp., 75 F. Supp. 2d 613, 621-25 (S.D. Tex. 1999) (denying a preliminary injunction and dismissing the case on summary judgment, holding that making an offer in the United States to make or sell a product outside of the United States was not within the statutory meaning of $\S 271$ (a)); Beloit Corp. v. Valmet Corp., No. 96-C-0087-C, 1997 U.S. Dist. LEXIS 21325, at *12-17 (W.D. Wis. July 15, 1997) (holding that an offer to sell a patented article occurring before issuance of the patent did not infringe because the con- 
tion to dismiss for lack of specific personal jurisdiction over a defendant based solely on the purported "offer to sell" activities and contacts. ${ }^{9}$

The substantive evaluations of personal jurisdiction and infringement based on "offers to sell" are not necessarily completely independent. In some of the personal jurisdiction cases, the courts have conflated the issues and conducted an "offer to sell" analysis-at least based upon the pleaded facts when viewed most favorably to the nonmoving party (i.e., the plaintiff) - to reach a conclusion regarding specific personal jurisdiction over a defendant. ${ }^{10}$ On the surface, it seems almost inevitable that these issues will be conflated, since the prevailing specific personal jurisdiction test used by the Federal Circuit in patent cases ${ }^{11}$ requires a nexus between the cause of action and the activities in the forum, which here are bound to be the same activities. If the in-forum activities suffice to support an alleged "offer to sell" for purposes of the patent infringement statute, the requisite contacts likely exist to justify the exercise of specific personal jurisdiction over the offering party. Conversely, if the in-forum activities cannot support an alleged "offer for sale," the exercise of personal jurisdiction will likely be found improper.

tract at issue had "a provision ... to work around any infringement problems that might arise" and the defendant did nothing more than design around the patent once it issued, and granting defendants' motion for partial summary judgment on the issue of infringement).

${ }^{9}$ See infra Part III.A for a discussion of some cases in this category, including: Wafios Mach. Corp. v. Nucoil Indus. Co., No. 03 Civ. 9865 (RWS), 2004 U.S. Dist. LEXIS 13674 (S.D.N.Y. July 21, 2004); Moldflow Corp. v. Simcon, Inc., 296 F. Supp. 2d 34 (D. Mass. 2003); Sitrick v. Freehand Sys., Inc., No. 02 C 1568, 2002 U.S. Dist. LEXIS 21140 (N.D. Ill. Oct. 29, 2002); Int'l Truck \& Engine Corp. v. Dawson Int'l Inc., 216 F. Supp. 2d 754 (N.D. Ind. 2002); Recycling Scis. Int'l, Inc. v. Soil Restoration \& Recycling, L.L.C., No. 00 C 0311, 2001 U.S. Dist. LEXIS 12989 (N.D. Ill. Aug. 23, 2001); USA Payments, Inc. v. Hotel Ramada of Nev., No. C-01-1450 VRW, 2001 U.S. Dist. LEXIS 9493 (N.D. Cal. June 21, 2001); Biometics, L.L.C. v. New Womyn, Inc., 112 F. Supp. 2d 869 (E.D. Mo. 2000).

${ }^{10}$ For cases justifying the exercise of personal jurisdiction based, in part, on an “offer to sell” analysis, see Sitrick, 2002 U.S. Dist. LEXIS 21140, at*9-15; Int'l Truck, 216 F. Supp. 2d at 759-62; Biometics, 112 F. Supp. 2d at 871-74. For cases declining to exercise personal jurisdiction, determining that an "offer to sell" was lacking, see Moldflow, 296 F. Supp. 2d at 42-44; USA Payments, 2001 U.S. Dist. LEXIS 9493, at *6-9.

${ }^{11}$ For a discussion of Akro Corp. v. Luker, 45 F.3d 1541 (Fed. Cir. 1995), which provided the prevailing test for personal jurisdiction used by the Federal Circuit in patent cases, see infra Part I.A. 
However, the apparent symmetry of this reasoning is illusory. ${ }^{12}$ The conflation, as manifest in the cases, results because the "offer to sell" query serves two purposes. It is an essential element for proving alleged infringement under the "offer to sell" provisions of the patent statutes. ${ }^{13}$ It is also the key-assuming no other contacts between the defendant and the forum state-to evaluating whether the exercise of specific personal jurisdiction can be justified under due process. ${ }^{14}$

The dual doctrinal function of the purported "offer to sell" enables two defensive approaches to "offer to sell" infringement litigation, the substantive avenue and the procedural avenue. ${ }^{15}$ Notwithstanding that both avenues ultimately may require addressing whether there was an "offer to sell," the disparate purposes served by the "offer to sell" determination within each context suggest that there is, or at

\footnotetext{
${ }^{12}$ As discussed infra Part III.C, this Comment advocates two improvements in the adjudication of "offer to sell" cases that could occur either separately or in parallel. The first suggestion is to broaden the interpretation of "offer to sell" in the personal jurisdiction inquiry. The second suggestion is to expand the scope of activities covered by "offer to sell" in the substantive infringement evaluation. The asymmetry between these two suggestions arises because broadening the personal jurisdiction test without expanding the substantive infringement test will give more patentees the opportunity to adjudicate their claims, but expanding the substantive infringement test without broadening the personal jurisdiction test will have no effect on the ability of patentees to vindicate their rights.

${ }^{13}$ See 35 U.S.C. $\$ 271$ (a) (2000) ("[W] hoever without authority makes, uses, offers to sell, or sells any patented invention . . infringes the patent."); $i d . \S 271$ (c) ("Whoever offers to sell or sells within the United States . . . a component of a patented machine, manufacture, combination or composition, or a material or apparatus for use in practicing a patented process, [with certain qualifications,] shall be liable as a contributory infringer."); id. § 271(e)(1) (exempting otherwise infringing activities, including offers to sell, if done "solely for uses reasonably related to the development and submission of information under a Federal law which regulates the manufacture, use, or sale of drugs or veterinary biological products"); id. §271(g) ("Whoever without authority ... offers to sell, sells, or uses within the United States a product which is made by a [patented] process ... shall be liable as an infringer, if the ... offer to sell, sale, or use of the product occurs during the term of such process patent.").

${ }^{14}$ See infra note 34 and accompanying text (discussing the second prong of the Akro personal jurisdiction test).

${ }^{15}$ The substantive argument, as utilized in Rotec Industries v. Mitsubishi Corp., 215 F.3d 1246, 1250 (Fed. Cir. 2000), MEMC Electronic Materials, Inc. v. Mitsubishi Materials Silicon Corp., 420 F.3d 1369, 1374-77 (Fed. Cir. 2005), and Fieldturf International, Inc. v. Sprinturf, Inc., 433 F.3d 1366, 1370 (Fed. Cir. 2006), is that the alleged activities did not constitute an "offer to sell" the patented article within the United States. See infra Part II.C (discussing the Federal Circuit's consideration of "offer to sell" cases on their merits). The procedural argument, as utilized in 3D Systems, Inc. v. Aarotech Laboratories, Inc., 160 F.3d 1373, 1376 (Fed. Cir. 1998) and HollyAnne Corp. v. TFT, Inc., 199 F.3d 1304, 1306 (Fed. Cir. 1999), is that the alleged activities within the forum were insufficient to justify the exercise of personal jurisdiction. See infra Part I.B (discussing the Federal Circuit's consideration of "offer to sell" cases on the issue of personal jurisdiction).
} 
least should be, a distinctly different meaning of "offer to sell" within each context. As a result, there should be considerable differences as to how these two avenues are analyzed by courts.

This Comment argues that there is a difference of meaning between an "offer to sell" for purposes of satisfying the patent infringement statute and an "offer to sell" giving rise to sufficient contacts within a forum to authorize specific personal jurisdiction. The dissimilarity of purpose served by the two applications necessitates that there be a difference. Additionally, this Comment discusses why these two tests should not be equated as a matter of doctrinal coherence; why courts have generally been unable to make the required distinction; and how patent infringement enforcement would be enhanced by judging each application of the "offer to sell" analysis under different criteria. ${ }^{16}$

This Comment provides a detailed analysis of the determination of "offer to sell" in both statutory patent infringement and personal jurisdictional circumstances. Part I explores the Federal Circuit test for personal jurisdiction in patent matters and then posits that in the application of its test for "offer to sell" infringement actions, the CAFC has reached beyond the jurisdictional question to make substantive pronouncements as to the meaning of the "offer to sell" language in the patent infringement statute. Part II discusses the interpretation of "offer to sell" within the purview of the patent infringement statute

\footnotetext{
${ }^{16}$ Since the enactment of TRIPs, many commentators have analyzed the meaning of the statutory "offer to sell" language in $§ 271$ (a), but no commentator has done so in the context of determining specific personal jurisdiction in patent infringement cases. See, e.g., Edwin D. Garlepp, An Analysis of the Patentee's New Exclusive Right to "Offer to Sell," 81 J. Pat. \& TRAdemark OfF. SOC'y 315, 329 (1999) (predicting that the new statutory grant will be interpreted as a separate and distinct right serving the underlying policies of patent protection); Timothy R. Holbrook, Liability for the "Threat of a Sale": Assessing Patent Infringement for Offering To Sell an Invention and Implications for the On-Sale Patentability Bar and Other Forms of Infringement, 43 SANTA CLARA L. REV. 751, 820-21 (2003) [hereinafter Holbrook, Liability for the "Threat of a Sale"] (arguing for a strong "offer to sell" patent infringement doctrine not bounded by the requirement of a formal offer or actual reduction to practice of the alleged infringing article); Timothy R. Holbrook, Territoriality Waning? Patent Infringement for Offering in the United States to Sell an Invention Abroad, 37 U.C. DAVIS L. REV. 701, 748-58 (2004) [hereinafter Holbrook, Territoriality Waning] (advocating a flexible but complex approach to allowing U.S. courts to consider the laws of the foreign jurisdiction in which a contemplated sale would be made when determining if offers made in the United States constitute infringement); Robert Ryan Morishita, Patent Infringement After GATT: What Is an Offer To Sell?, 1997 UTAH L. REV. 905, 916-30 (analyzing the meaning of an "offer to sell" in the context of the constitutional protections of free speech); David Sulkis, Note, Patent Infringement by Offer To Sell: Rotec Industries, Inc. v. Mitsubishi Corporation, 38 Hous. L. REV. 1099, 1127-28 (2001) (arguing that "offers to sell" should be treated on par with the traditional forms of infringement of "makes, uses, or sells").
} 
and finds that analogies to the "offer" in contract law and the "on sale" bar to patenting are both inadequate to serve the economic purpose of "offer to sell" infringement liability. Part III argues that the disparate purposes served by the two "offer to sell" analyses necessitate that they be treated as doctrinally distinct, illustrates how various federal district courts have gone astray due to lack of clear guidance from the Federal Circuit as to the differences and the import of those differences, and concludes that the meaning of "offer to sell" must be interpreted specifically within its discrete and particular personal jurisdictional and substantive contexts if the "offer to sell" patent infringement statute is to evolve meaningfully as a distinct and viable cause of action.

\section{Evaluating Specific Personal Jurisdiction in "OFFER TO SELL" PATENT INFRINGEMENT CASES}

A fundamental reason for the establishment of the Court of Appeals for the Federal Circuit ${ }^{17}$ was to promote national uniformity in the adjudication of patent matters. ${ }^{18}$ Therefore, when evaluating whether the exercise of personal jurisdiction over an alleged patent infringer is proper, the Federal Circuit applies its own law "rather than that of the regional circuit in which the case arose."19 This standard applies equally whether the defendant is an alleged infringer or a patentee in a declaratory action. ${ }^{20}$

${ }^{17}$ Federal Courts Improvement Act of 1982, Pub. L. No. 97-164, 96 Stat. 25 (bringing into existence the Court of Appeals for the Federal Circuit on Oct. 1, 1982 by merging the appellate division of the Court of Claims and the Court of Customs and Patent Appeals).

${ }^{18}$ H.R. REP. NO. 97-312, at 23 (1981) (“[T] he central purpose [of the Federal Courts Improvement Act] is to reduce the widespread lack of uniformity and uncertainty of legal doctrine that exist in the administration of patent law."); S. REP. NO. 97-275, at 5 (1981) (contemplating that " $[\mathrm{t}]$ he creation of the Court of Appeals for the Federal Circuit will produce desirable uniformity" and "will increase doctrinal stability in the field of patent law").

${ }^{19}$ Akro Corp. v. Luker, 45 F.3d 1541, 1543 (Fed. Cir. 1995). Accordingly, the district courts follow the CAFC's approach. See infra note 196 and accompanying text (discussing the district courts' obligation to follow Federal Circuit precedent in patent cases).

${ }^{20}$ Regardless which party challenges the exercise of personal jurisdiction, the issue is "intimately involved with the substance of the patent laws." Akro, 45 F.3d at 1543. Different personal jurisdiction issues will be invoked in a declaratory action, since the contacts determination will normally be based on cease and desist letters sent by the patentee to the alleged infringer, or on the initiation of licensing negotiations between the patentee and the alleged infringer. See, e.g., Silent Drive, Inc. v. Strong Indus., Inc., 326 F.3d 1194, 1202 (Fed. Cir. 2003) (deciding under Akro's third prong (reasonableness) that "the sending of letters threatening infringement litigation is not sufficient to 


\section{A. The Federal Circuit Test for Personal Jurisdiction in Patent Cases}

Each circuit court is free to develop its own test for the exercise of personal jurisdiction, framed by relevant Supreme Court precedents, ${ }^{21}$ and prior to the creation of the $\mathrm{CAFC},{ }^{22}$ these various regional circuit tests were applied in patent litigation. ${ }^{23}$ The Federal Circuit recognized early in its existence its "mandate to achieve uniformity in patent matters" as "the spirit and guiding principle of th [e] court."

However, more than a decade passed until the Federal Circuit had the opportunity to assess the need for a uniform personal jurisdiction standard regarding matters within its exclusive grant of appellate subject matter jurisdiction. ${ }^{25}$ The analytical framework of Beverly Hills Fan

confer personal jurisdiction"); Hildebrand v. Steck Mfg. Co., 279 F.3d 1351, 1356 (Fed. Cir. 2002) (holding that contacts "for the purpose of warning against infringement or negotiating license agreements" are not sufficient to support a fair and reasonable exercise of personal jurisdiction); Red Wing Shoe Co. v. Hockerson-Halberstadt, Inc., 148 F.3d 1355, 1359-62 (Fed. Cir. 1998) (declining to exercise personal jurisdiction where the patentee sent a cease and desist letter that included an entreaty to license to an alleged infringer); Genetic Implant Sys., Inc. v. Core-Vent Corp., 123 F.3d 1455, 1458-60 (Fed. Cir. 1997) (finding personal jurisdiction in a declaratory judgment action for invalidity and noninfringement where the patentee sent letters to an alleged infringer threatening suit and entered into a licensing agreement with a distributor through which the patentee's products were sold in the state).

${ }^{21}$ For an extensive review of the current state of personal jurisdiction in the federal courts, see 4 CHARLES Alan Wright \& ARTHUR R. Miller, FEDERAL PraCtice AND PROCEDURE $§ \S 1063-1068.1$ (3d ed. 2004).

${ }^{22}$ See supra note 17 and accompanying text (discussing the establishment of the CAFC by the Federal Courts Improvement Act of 1982).

${ }^{23}$ See, e.g., Dakota Indus., Inc. v. Dakota Sportswear, Inc., 946 F.2d 1384, 1387 (8th Cir. 1991) (considering only "whether the exercise of [personal] jurisdiction is proper under the forum state's long-arm statute" and whether it "comports with due process"); Max Daetwyler Corp. v. R. Meyer, 762 F.2d 290, 293, 294 (3d Cir. 1985) (considering it both fair and reasonable under the Fifth Amendment " $[\mathrm{t}] \mathrm{o}$ aggregate the national contacts of an alien defendant in order to obtain personal jurisdiction," in the case where the forum state's long-arm "statute expressly incorporates the federal due process standard”); Horne v. Adolph Coors Co., 684 F.2d 255, 260 (3d Cir. 1982) (refusing to construe a due process limitation on the exercise of personal jurisdiction from federal statutory venue restrictions for patent cases); Stabilisierungsfonds Fur Wein v. Kaiser Stuhl Wine Distribs. Pty. Ltd., 647 F.2d 200, 204 (D.C. Cir. 1981) (discussing at length why federal courts, in cases where Congress has made no provision for services of process, "refer to local statutes or rules governing competence"); Honeywell, Inc. v. Metz Apparatewerke, 509 F.2d 1137, 1143 (7th Cir. 1975) (holding it appropriate to "appl[y] the 'minimum contacts' standard to federal question cases in which [personal] jurisdiction [i]s at issue"). 1984).

${ }^{24}$ Panduit Corp. v. All States Plastic Mfg. Co., 744 F.2d 1564, 1574 (Fed. Cir.

${ }^{25}$ The Federal Circuit's jurisdiction is granted by 28 U.S.C. $§ 1295$ (2000). In particular, § 1295(a)(1) grants exclusive jurisdiction to the Federal Circuit over appeals of federal district court final decisions arising out of certain cases in which origi- 
Co. v. Royal Sovereign Corp. ${ }^{26}$ set the stage for the Federal Circuit to enunciate, within a year, its test for personal jurisdiction that has been followed since. ${ }^{27}$

As a preliminary matter, the CAFC in Akro recognized that "[b]ecause subject matter jurisdiction [in a patent infringement] action exists by virtue of a federal question," a Fifth Amendment due process analysis was appropriate. ${ }^{28}$ However, finding that the Supreme Court had never reached the due process issue in a federal question case, ${ }^{29}$ the Akro court fashioned a test based on the Fourteenth Amendment due process jurisprudence emanating from International Shoe and its progeny. ${ }^{30}$ Nevertheless, the potential difference of interpretation between Fifth Amendment due process and Fourteenth Amendment due process ${ }^{31}$ could be critical in a patent case involving an alien defendant. While there is always a forum within the United States where a party domiciled in another state is amenable to suit, the same is not true for a party domiciled in a foreign country. ${ }^{32}$

nal jurisdiction "was based, in whole or in part, on" 28 U.S.C. § 1338 (pertaining to patents, plant variety protection, copyrights, and trademarks).

${ }^{26} 21$ F.3d 1558, 1565-72 (Fed. Cir. 1994) (noting the lack of uniformity among the circuit courts with regard to the test for personal jurisdiction and declaring that the application of a uniform Federal Circuit standard to matters unique to patent law would "promote our mandate of achieving national uniformity in the field of patent law.").

${ }^{27}$ See Akro, 45 F.3d at 1545-46. North American Philips Corp. v. American Vending Sales, Inc., 35 F.3d 1576, 1579 (Fed. Cir. 1994), decided after Beverly Hills Fan but before Akro, also addressed the issue of personal jurisdiction in a patent infringement suit, albeit less comprehensively.

${ }^{28}$ Akro, 45 F.3d at 1544. 28 U.S.C. $\$ 1331$ conveys subject matter jurisdiction to the federal courts for federal question cases, including civil actions arising under 35 U.S.C. $\S 271$ (the federal patent infringement statute). Moreover, the federal district courts have exclusive "original jurisdiction of any civil action arising under any Act of Congress relating to patents.” 28 U.S.C. $\$ 1338$ (a) (2000).

${ }^{29}$ Akro, 45 F.3d at 1545 n.4.

${ }^{30} I d$. at 1544-49 (relying on International Shoe Co. v. Washington, 326 U.S. 310, 316 (1945), for the proposition that "due process requires only that... [the defendant] have certain minimum contacts" with the forum).

${ }^{31}$ The Supreme Court has not decided whether there is any difference with regard to the exercise of personal jurisdiction. See Asahi Metal Indus. Co. v. Superior Court, 480 U.S. 102, 113 n.* (1987) (declining to find "an occasion ... to determine whether Congress could, consistent with the Due Process Clause of the Fifth Amendment, authorize federal court personal jurisdiction over alien defendants based on the aggregate of national contacts, rather than on the contacts between the defendant and the State in which the federal court sits").

32 GARY B. BORN, INTERNATIONAL Civil Ligitation in United STATES Courts 93 (3d ed. 1996) ("Assertions of jurisdiction over foreign defendants often raise different issues than assertions of jurisdiction over U.S. defendants from other states of the Union."). Personal jurisdiction can always be asserted in the state of domicile of a non- 
The Akro due process test involves three successive determinations: whether the activities or contacts in the forum were purposefully directed, ${ }^{33}$ whether the cause of action "arise[s] out of or relate[s] to those activities," ${ }^{34}$ and whether the exercise of personal jurisdiction would be constitutionally reasonable. ${ }^{35} \quad$ The first prong of Akro captures the traditional minimum contacts analysis, and the third prong bounds personal jurisdiction within the constitutional guarantee of due process. With regard to the analysis of "offer to sell" infringement, this Comment has no quarrel with the Federal Circuit's interpretation of those prongs.

The second prong of the Akro test is "the divining rod that separates specific jurisdiction cases from general jurisdiction cases... [and] ensures that the element of causation remains in the forefront of the due process investigation." ${ }^{36}$ Critically, the Akro court endorsed the view that the disjunctive nature of the "constitutional catchphrase" ${ }^{37}$ requiring that a cause of action "arise out of or relate to" contacts within the forum portends "added flexibility and signal[s] a relaxation of the applicable standard." ${ }^{38}$ The CAFC, along with the other circuit courts, has been left to its own determination of the req-

alien defendant. Milliken v. Meyer, 311 U.S. 457, 462 (1940); accord RESTATEMENT (FIRST) OF CONFLICT OF LAWS $§ 47(1)$ (b) (1934) ("A state has jurisdiction over a person ... if he is domiciled in the state although not present there ...."). The Akro court, dealing with a defendant of American domicile, was spared the issue of an alien defendant. 45 F.3d at 1542. Although one of the codefendants in Beverly Hills Fan was an alien, the court in that case applied its analysis as if the Fifth and Fourteenth Amendment due process issues were identical. $21 \mathrm{~F} .3 \mathrm{~d}$ at 1560, 1565-69.

33 Akro, 45 F.3d at 1546; see also Hanson v. Denckla, 357 U.S. 235, 253 (1958) (requiring "that there be some act by which the defendant purposely avails itself of the privilege of conducting activities within the forum State" before a state can invoke personal jurisdiction).

${ }^{34}$ Akro, 45 F.3d at 1545 (quoting Burger King Corp. v. Rudzewicz, 471 U.S. 462, 472 (1985)) (internal quotation marks omitted); see also Helicopteros Nacionales de Colombia, S.A. v. Hall, 466 U.S. 408, 414 (1984) (holding that the exercise of personal jurisdiction meets the fundamental requirements of due process " $[w]$ hen a controversy is related to or 'arises out of' a defendant's contact with the forum").

${ }^{35}$ Akro, 45 F.3d at 1545.

${ }^{36}$ Ticketmaster-New York, Inc. v. Alioto, 26 F.3d 201, 207 (1st Cir. 1994). The second prong of Akro arguably attempts to focus the personal jurisdiction test on "the relationship among the defendant, the forum, and the litigation" but is overly constraining. Shaffer v. Heitner, 433 U.S. 186, 204 (1977); see also infra Part III (distinguishing questions of personal jurisdiction from questions of substantive patent infringement). For the seminal analysis in which the terms "specific jurisdiction" and "general jurisdiction" were first coined, see Arthur T. von Mehren \& Donald T. Trautman, Jurisdiction to Adjudicate: A Suggested Analysis, 79 HARV. L. REV. 1121, 1136 (1966).

${ }^{37}$ Ticketmaster-New York, 26 F.3d at 206.

${ }^{38}$ Akro, 45 F.3d at 1547 (quoting Ticketmaster-New York, 26 F.3d at 206) (internal quotation marks omitted). 
uisite "nexus between the defendant's contacts and the plaintiff's cause of action" "distinction between controversies that 'relate to' a defendant's contacts with a forum and those that 'arise out of' such contacts." ${ }^{\text {" }}$ Because it has recognized that there are "few guideposts" on this aspect of the personal jurisdiction inquiry, ${ }^{41}$ the CAFC must be willing to draw from a broader range of due process jurisprudence in shaping the meaning of the second prong. ${ }^{42}$

In defending against a motion to dismiss, "the plaintiff bears the burden to establish the court's [personal] jurisdiction [over the defendant], which normally is not a heavy one." Most commonly, the plaintiff need make only a prima facie showing when the court bases its decision solely on the parties' pleadings and affidavits, but otherwise "bears the ultimate burden of demonstrating that the court's personal jurisdiction over the defendant exists by a preponderance of the evidence." Additionally, "all factual disputes must be resolved in [the plaintiff's] favor in order to evaluate its prima facie showing of jurisdiction." ${ }^{45}$ Further, "the Supreme Court has intimated that in the case of a challenge to the constitutional fairness and reasonableness of the chosen forum, the burden is on the defendant." ${ }^{46}$

${ }^{39}$ Ticketmaster-New York, 26 F.3d at 206.

${ }^{40}$ Helicopteros, 466 U.S. at 415 n.10.

${ }^{41}$ Akro, 45 F.3d at 1547.

${ }^{42}$ In addition to the cases cited in Part II.A, there are a number of other applicable cases addressing the necessary relationship between the cause of action and the inforum contacts of the defendant. See, e.g., Calder v. Jones, 465 U.S. 783, 789 (1984) (embracing the "effects" test for conduct occurring outside of the forum but causing harm within the forum); Keeton v. Hustler Magazine, Inc., 465 U.S. 770, 781 (1984) (holding that due process was satisfied when the defendant "continuously and deliberately exploited" the forum market); World-Wide Volkswagen Corp. v. Woodson, 444 U.S. 286, 297 (1980) (holding that mere foreseeability is insufficient to justify the exercise of personal jurisdiction but rather that due process critically requires "that the defendant's conduct and connection with the forum State are such that he should reasonably anticipate being haled into court there").

${ }^{43}$ 5B WRIGHT \& MiLler, supra note 21, § 1351; accord 35B C.J.S. Federal Civil Procedure $\$ 832$ (2003) ("[T] he plaintiff bears the burden of establishing that the court has jurisdiction over the defendant.”).

${ }^{44}$ 5B WRIGHT \& MiLLER, supra note 21, § 1351; accord 35B C.J.S., supra note , § 832 (" $[\mathrm{T}]$ he plaintiff need only make a showing of personal jurisdiction, with prima facie evidence being sufficient.”).

${ }^{45}$ Deprenyl Animal Health, Inc. v. Univ. of Toronto Innovations Found., 297 F.3d 1343, 1347 (Fed. Cir. 2002).

${ }^{46}$ 5B WRIGHT \& MiLleR, supra note 21, § 1351. 


\section{B. The Federal Circuit's Application of the Akro Test to "Offer To Sell" Patent Infringement Cases}

The CAFC has twice adjudicated the issue of personal jurisdiction in the context of "offer to sell" infringement actions. Both times it has unnecessarily reached a substantive analysis of whether an "offer to sell" existed under the patent infringement statute by stretching beyond the nexus requirement set forth in the second prong of Akro. ${ }^{47}$ The resulting dicta has created confusion since it apparently conflicts with Rotec's later holding that "offer to sell" should be interpreted to require an "offer" as used in contract parlance. ${ }^{48}$ Viewed in this light, both the doctrinal and policy purposes of distinguishing between the statutory and personal jurisdictional meanings of "offer to sell" ${ }^{\text {"9 }}$ illuminate the failure of the Federal Circuit to fully appreciate the import of procedural posture on the viability of this fledgling form of patent infringement. ${ }^{50}$

The Federal Circuit first grappled with a motion to dismiss for lack of personal jurisdiction ${ }^{51}$ in the context of an "offer to sell" infringement action in 3D Systems, Inc. v. Aarotech Laboratories, Inc. ${ }^{52}$ 3D Systems, a leading manufacturer of rapid prototyping equipment, ${ }^{53}$ filed suit in the Central District of California, alleging infringement of its patents, as well as trade libel and unfair competition, by its competitor

${ }^{47}$ See supra note 34 and accompanying text .

${ }^{48}$ See Rotec Indus., Inc. v. Mitsubishi Corp., 215 F.3d 1246, 1254-55 (Fed. Cir. 2000) ("[W]e ... define $\$ 271$ (a)'s 'offer to sell' liability according to the norms of traditional contractual analysis.”); E. ALLAN FARNSWORTH, CONTRACTS § 3.3, at 112-13 (3d ed. 1999) (defining an offer "as a manifestation to another of assent to enter into a contract if the other manifests assent in return").

${ }^{49}$ See infra Part II.C (discussing the Federal Circuit's interpretation of "offer to sell”).

${ }^{50}$ By adopting an unnecessarily stringent analysis for personal jurisdiction for "offer to sell" patent infringement cases, the Federal Circuit has (perhaps unwittingly) greatly decreased the ability of patentees to litigate these cases on the merits, thereby eliminating many opportunities for the district courts to develop a coherent body of law in this area and impairing the effectiveness of the policy embodied in the "offer to sell" statutory provision. See infra Part II.A (discussing the additional statutory rights intended to be protected by the "offer to sell" provision); infra Part III.B (arguing that the Federal Circuit's application of the second prong of Akro has been overly rigid, thereby distorting due process at plaintiffs' expense).

${ }^{51}$ FED. R. CIV. P. 12(b) (2).

${ }^{52} 160$ F.3d 1373 (Fed. Cir. 1998).

${ }^{53}$ Rapid prototyping equipment "is used to produce three-dimensional prototype models of products during the design and development phase of [those] products." $3 D$ Sys., 160 F.3d at 1376. 
Aarotech. ${ }^{54}$ The district court dismissed for lack of personal jurisdiction over all three defendants. ${ }^{55}$

On appeal, the Federal Circuit reversed with respect to defendant Aaroflex, applying the Akro test ${ }^{56}$ and breathed life into the previously untested "offer to sell" provision in $\S 271(\mathrm{a}) .{ }^{57}$ The alleged infringing activities of Aaroflex comprised mailing "eight letters containing price quotations and descriptions of the merchandise for sale," as well as solicitation letters and other "promotional materials," to prospective customers in the forum state. ${ }^{5}$

The court concluded that the solicitations, promotional letters, and price quotations satisfied the first prong of the Akro test, as these pre-sales activities were "clearly purposefully directed at" the forum. ${ }^{59}$ Similarly, the court found that the claim against Aaroflex arose out of those purposefully directed activities, thus satisfying the second Akro prong. ${ }^{60}$ Determined to make the prohibition against offers to sell more than just hollow verbiage, the court opined that the "offer to sell" statutory language was intended "to prevent exactly the type of activity Aaroflex ha[d] engaged in, namely, generating interest in a potential infringing product to the commercial detriment of the rightful patentee."

In so doing, the court, perhaps anxious to shape the meaning of the new statutory term, overreached by making substantive pronouncements when its appellate jurisdiction was founded only on procedural decisions. ${ }^{62}$ Such overreaching is not harmless since these

\footnotetext{
${ }^{54}$ Joined as defendants in the suit were Aarotech Laboratories, Inc., an Oklahoma corporation based in Virginia; Aaroflex, Inc., a subsidiary of Aarotech Laboratories and a West Virginia corporation with its principal place of business in Virginia; and Albert C. Young, the president and chairman of the board of Aaroflex. Plaintiff 3D Systems was a corporation based in California. Id. at 1375-76.

${ }^{55} I d$. at 1375.

56 See supra notes 33-35 and accompanying text.

${ }^{57}$ See 3D Sys., 160 F.3d at 1378 (acknowledging that this opportunity to apply the recently added "offer to sell" language of 35 U.S.C. $\$ 271$ (a) was "an issue of first impression"). The relevant personal jurisdiction analysis and holding of the court, for purposes of evaluating the development of this doctrine in the Federal Circuit, pertain to Aaroflex. The dismissals for lack of personal jurisdiction with respect to Aarotech Laboratories and Albert C. Young were affirmed by the CAFC. Id. at 1381.

${ }^{58} I d$. at 1376 .

${ }^{59} I d$. at 1378; see supra note 33 and accompanying text.

${ }^{60} 3 D$ Sys., 160 F.3d at 1379; see supra note and accompanying text (identifying the second prong of the Akro test).

${ }^{61} 3 D$ Sys., 160 F.3d at 1379.

${ }^{62}$ See infra note 87 (noting that neither HollyAnne nor 3D Systems was on appeal from a final decision on the merits).
} 
early "offer to sell" infringement cases created guiding, if not binding, precedent for the district courts. ${ }^{63}$

The court could have achieved the same result by simply acknowledging the nexus between the cause of action under the statute and the purportedly infringing activities, finding either that the former "arises out of" the latter, or that they are "related to" one another; ${ }^{64}$ the plaintiff had met the prima facie burden required on the pleadings. ${ }^{65}$ Instead, the court took de facto (although obviously not de jure) jurisdiction of the case in order to declare, in dictum, principles guiding the establishment of substantive legal boundaries on "offer to sell" infringement. ${ }^{66}$ Compounding this error and ignoring Akro's discussion of a flexible second prong, the court, without comment, stiffened the second prong test, deeming it to be "whether the cause of action arises out of or directly relates to [the in-forum] activities." ${ }^{\prime 67}$

Finally, the court affirmatively answered the due process reasonableness question of the third Akro prong, rejecting as untenable the argument of inconvenience in defending a suit in the same forum where it was recently convenient to market one's products. ${ }^{68}$

In HollyAnne Corp. v. TFT, Inc., the Federal Circuit again unnecessarily reached a substantive determination of the meaning of "offer to sell," examining the facts in detail and determining that a purported "mere offer to donate, where a donation is never made, cannot be an offer for sale" and therefore does not fall within the purview of the statutory prohibition. ${ }^{69}$ HollyAnne, a manufacturer of patented cable

${ }^{63}$ See infra note 196 and accompanying text (citing cases following the precedent created in 3D Systems and HollyAnne).

${ }^{64}$ See Int'l Shoe Co. v. Washington, 326 U.S. 310, 315, 320 (1945) (finding sufficient "minimum contacts" in the "mere solicitation of orders for the purchase of goods within [the] state"); see also World-Wide Volkswagen Corp. v. Woodson, 444 U.S. 286, 295 (1980) (declining jurisdiction because, inter alia, defendants did not "solicit... business ... through advertising reasonably calculated to reach the State").

${ }^{65}$ See supra notes 43-44 and accompanying text (reviewing the procedural burdens involved in a motion to dismiss for lack of personal jurisdiction).

${ }^{66}$ The court decided de novo the substantive issue that was not decided below, effectively acting as a trial court but with an incomplete record, since the case below was dismissed on a FED. R. CIV. P. 12(b) (2) motion.

${ }^{67}$ 3D Sys., Inc., v. Aarotech Labs., Inc., 160 F.3d 1373, 1378 (Fed. Cir. 1998) (emphasis added); see supra notes 34, 38 and accompanying text (defining the test for Akro's second prong and noting its potential flexibility).

${ }^{6} 3 D$ Sys., 160 F.3d at 1380; see supra note 35 and accompanying text (defining Akro's third prong).

199 F.3d 1304, 1309 (Fed. Cir. 1999). 
television encoder devices, ${ }^{70}$ sued in the District of Nebraska, accusing TFT of making, using, offering to sell, and selling infringing devices. ${ }^{71}$ However, specific personal jurisdiction in the forum was premised only on "a newspaper article describing TFT's offer, at a private meeting with school officials, to donate the allegedly infringing devices to a school system and a local cable television station," which HollyAnne characterized as an "offer to sell." ${ }^{72}$ The district court dismissed for lack of personal jurisdiction over TFT. ${ }^{73}$

As in $3 D$ Systems, the CAFC in HollyAnne took de facto jurisdiction over the case, confusing the absence of a cause of action with the lack of personal jurisdiction. Instead of restricting itself to an appropriately narrow holding, the CAFC propounded, in dictum, that an offer to make a donation "include[s] none of the hallmarks of a potential commercial transaction" 74 and is not the "legal equivalent of an "offer to sell' for purposes of patent infringement" 75 under $\S 271(\mathrm{a})$. This language may have been warranted in a dismissal for "failure of the pleading to state a claim upon which relief can be granted" ${ }^{, 6}$ or in a grant of summary judgment where no material facts were in genuine dispute and the alleged infringer was entitled to prevail as a matter of law, ${ }^{77}$ but was superfluous in assessing the existence of a requisite nexus between the cause of action and the alleged in-forum activities.

By not confining its analysis to the procedural posture of the case, the HollyAnne court based its dismissal on a failure to meet the nexus requirement of the second prong of Akro, not because the cause of action did not "arise out of" the defendant's activities in the forum state but because there was in fact no cause of action. ${ }^{78}$ Additionally,

${ }^{70}$ HollyAnne held two patents on these devices: U.S. Patent No. 4,575,750 (filed May 31, 1984) (issued Mar. 11, 1986) and U.S. Patent No. 5,548,323 (filed Mar. 30, 1994) (issued Aug. 20, 1996). HollyAnne, 199 F.3d at 1305.

${ }^{71}$ Id. HollyAnne was a Nebraska corporation and TFT was a California corporation.

${ }^{72} I d$. at 1308 .

${ }^{73} I d$. at 1305 . The district court also transferred venue to the Northern District of California, a transfer reversed as improper by the CAFC. Id. at 1305, 1310.

${ }^{74} I d$. at 1310 .

${ }^{75} I d$. at 1308 .

${ }_{77}^{76}$ FED. R. CIV. P. 12(b) (6).

${ }^{77}$ FED. R. CIV. P. 56(c); see also BLACK's LAW DiCTIONARY 1476 (8th ed. 2004) (defining summary judgment as "[a] judgment granted on a claim about which there is no genuine issue of material fact and upon which the movant is entitled to prevail as a matter of law").

${ }^{78}$ See HollyAnne, 199 F.3d at 1310 (holding that because the offer to donate was not an "offer to sell," the action could not give rise to a cause of action under $\S 271$ ); see also supra note 34 and accompanying text (defining Akro's second prong). 
the court sustained the unexplained stiffening (which originated in $3 D$ Systems) of the relatedness branch of the nexus test by repeating the requirement that the cause of action be directly related to the defendant's in-forum contacts. ${ }^{79}$

Since the HollyAnne court accepted-or at least declined to find to the contrary-that the plaintiff alleged sufficient facts to support a colorable claim arising out of $\S 271(\mathrm{a}){ }^{80}$ patent infringement jurisprudence would have been better served by the exercise of personal jurisdiction and a remand for adjudication (likely summary judgment for the defendants, absent additional evidence of an actual offer to sell) on the merits. Instead, adhering to the prima facie standard, ${ }^{81}$ the court intimated that the purposefully directed activities requirement of the first Akro prong ${ }^{82}$ was not satisfied ${ }^{83}$ but declined to base its dismissal for lack of personal jurisdiction on that failing, apparently because that point was uncontested by the defendants. ${ }^{84}$ Nonetheless, such a dismissal would have been preferable to muddling the fledgling "offer to sell" infringement doctrine with an extraneous substantive pronouncement.

That the Federal Circuit overreached in both 3D Systems and HollyAnne is further evidenced by what the court failed to consider in those two decisions. The act of infringement under $\S 271$ (a) nominally requires two substantive elements: that infringing conduct (i.e., make, use, offer to sell, or sell) have taken place and that the article or method that is the subject of such conduct be claimed as a patented

${ }^{79}$ HollyAnne, 199 F.3d at 1308; see supra note 67 and accompanying text (describing the "stiffened" test to be "whether the cause of action arises out of or directly relates to [the in-forum] activities"). The impact of stiffening the "related to" branch of the nexus requirement is unclear from subsequent cases and may be inconsequential if the relevant portions of the $3 D$ Systems and HollyAnne opinions reaching this issue are determined by later courts to be dicta, as is advocated herein.

${ }^{80} I d$. at 1309 (noting that the plaintiff submitted an affidavit alleging that the defendant "distributed products in Nebraska that allegedly infringe").

${ }^{81}$ See 5B Wright \& Miller, supra note 21, § 1351 (describing the plaintiff's burden to demonstrate the court's personal jurisdiction over the defendant by a preponderance of the evidence).

${ }^{82}$ See supra note 33 and accompanying text.

83 See HollyAnne, 199 F.3d at 1308 (noting that "HollyAnne does not cite any efforts by TFT to quote prices, solicit orders or send promotional sales letters to [forum] residents" and that HollyAnne had conceded at oral argument "that the only specific evidence it had of any [in-forum] activity ... was a newspaper article describing . . . a private meeting with school officials" at which TFT made the alleged offer).

${ }^{84}$ See id. (declining to base its holding on the first Akro prong, apparently because the alleged infringer "[did] not challenge the assertion that the [alleged 'offer to sell'] satisfie[d] the 'directing activities to residents of the forum' prong of the test"). 
invention whose patent is still in force. ${ }^{85}$ Each element is equally indispensable, and both must be found to support a finding of infringement. Yet, while both opinions devote extensive consideration to the question of infringing conduct, neither even mentions whether the article or method is claimed by the plaintiff's patent. ${ }^{86}$

If the CAFC understood that it would need to take jurisdiction of the case to decide the latter issue, why did it not realize the same with regard to the former issue? ${ }^{87}$ This disparity of logic is more strongly apparent in $3 D$ Systems than it is in HollyAnne. In holding the defendant's in-forum activities insufficient to establish personal jurisdiction, the HollyAnne court might plausibly claim to have ruled based on the easier issue, since failure on either would be dispositive, at least within the substantive analytical framework utilized. ${ }^{88}$ But in $3 D$ Systems, the court held that personal jurisdiction was proper based on only one of the two essential elements in $\S 271(\mathrm{a})$, completely ignoring the other. $^{89}$

There are two competing explanations for this failure to examine whether the article purportedly offered for sale was covered within the scope of enforceable patent claims: either the court refrained from a claim construction in order to avoid that often complex and timeconsuming evaluation, ${ }^{90}$ or the court erred in reaching the determina-

${ }^{85} 35$ U.S.C. $\$ 271$ (a) (2000).

${ }^{86}$ In contrast to the CAFC's miscue, see Halmar Robicon Group, Inc. v. Toshiba Int'l Corp., No. 98-501, 1999 U.S. Dist. LEXIS 19869, at*6-7 (W.D. Pa. Nov. 17, 1999) (recognizing that there is "simply ... no way in which to examine [plaintiff's] Motion for Partial Summary Judgment for patent infringement without first completing a claim construction on the [patent at issue]").

${ }^{87}$ The CAFC had appellate jurisdiction over both HollyAnne and 3D Systems under 28 U.S.C. § 1295 (a) (1) (2000), which vests the Federal Circuit with exclusive jurisdiction over appeals from district court decisions based on 28 U.S.C. $\$ 1338$ (a) (2000) (civil actions relating to patents, plant variety protection, copyrights, mask works, designs, trademarks, and unfair competition). HollyAnne was on appeal from an order dismissing the case for lack of personal jurisdiction and improper venue and ordering a change of venue. 199 F.3d at 1305. 3D Systems was on appeal from an order dismissing for lack of personal jurisdiction. $160 \mathrm{~F} .3 \mathrm{~d}$ at 1375 . However, neither was on appeal from a final decision on the merits, and therefore the CAFC should not have been able to exercise its jurisdiction to decide substantive matters at issue in either case that had never been decided by either respective district court.

${ }^{88}$ See HollyAnne, 199 F.3d at 1310 (concluding that the Nebraska district court correctly dismissed for lack of personal jurisdiction because of the absence of infringing conduct and not because the article allegedly offered for sale was not the subject of a valid patent claim).

${ }^{89}$ See 3D Sys., 160 F.3d at 1379 (focusing solely on whether there was an "offer to sell”).

${ }^{90}$ Such a determination is often the subject of an entirely separate preliminary proceeding. See supra note 7 (discussing "Markman" hearings). 
tion of whether the in-forum activities constituted an "offer to sell" for purposes of the infringement statute. The notion that the CAFC shirked its duties must be disregarded as implausible; if a claim construction was required to decide whether a cause of action arose out of or was related to the in-forum activities, the court would have been obligated to undertake it. The conclusion, therefore, is that in a good faith but premature effort to fulfill its broad mandate of fostering uniform application of the new statutory patent infringement provision in the district courts, ${ }^{91}$ the court imprudently set forth the scope of activities falling within the "offer to sell" prohibition.

\section{INTERPRETING "OFFER TO SELL" INFRINGEMENT IN THE CONTEXT OF THE PATENT STATUTES AND CONTRACT LAW}

The meaning given to "offer to sell" in $\$ 271$ (a) is critical in defining the scope of this aspect of the exclusive right granted to a patentee. Relevant context for this definitional task may be found in both the intended purpose of "offer to sell" infringement protection and the interpretation of the putatively related concepts of the contractual "offer" and the "on sale" bar to patentability.

\section{A. The Addition of "Offer To Sell" as an Independent Statutory Grant to the Patentee}

A straightforward textual conclusion from $\S 271(\mathrm{a})$, post URAA modifications, ${ }^{92}$ is that an "offer to sell" a patented article is "sufficient to constitute patent infringement[, yet t] his new exclusive right is qualified by the addition of $\S 271(\mathrm{i}),{ }^{, 93}$ as well as by other language in $\S 271$ (a) itself. To be an infringing "offer to sell" under the combined language of $\S 271$ (a) and (i), the offer, at a minimum, must be made in the United States ${ }^{94}$ and the intended sale must be contemplated to

\footnotetext{
${ }^{91}$ See supra notes 18, 24 and accompanying text (describing the foundation of the mandate for fostering uniform application).

${ }_{92}$ See supra note 2 and accompanying text (discussing the URAA modifications).

${ }^{93}$ Garlepp, supra note 16, at 315 . Section 271 (i) provides that "[a]s used in this section, an 'offer for sale' or an 'offer to sell' by a person other than the patentee, or any designee of the patentee, is that in which the sale will occur before the expiration of the term of the patent." 35 U.S.C. $\$ 271$ (i) (2000).

${ }^{94}$ See 35 U.S.C. $\$ 271$ (a) ("[W] hoever without authority makes, uses, offers to sell, or sells any patented invention, within the United States or imports into the United States any patented invention during the term of the patent thereof, infringes the patent."). There is considerable debate as to the modification of "offer to sell" by the phrase "in the United States" in $§ 271$ (a). The most broad and textual, yet simplistic, reading is advocated by David Sulkis. See Sulkis, supra note 16, at 1103, 1124-28 (arguing that an offer made in the United States is "an infringement of the patentee's exclu-
} 
occur before the expiration of the patent term. ${ }^{95}$ Whether the new statutory grant of $\S 271$ (a) is construed broadly or narrowly with respect to where the intended sale is to be consummated, the "offer to sell" language effectively extends a patentee's exclusive rights to prevent infringers from deriving pecuniary benefits from the invention (and thus potentially diminishing the financial rewards accruing to the patentee) without the patentee's consent. ${ }^{96}$ Yet undetermined, however, is the range of activities captured within the scope of the "offer to sell" statutory language so as to constitute infringement.

sionary right, regardless of whether or where the product is ultimately sold, or whether or where it is delivered"); accord Wesley Jessen Corp. v. Bausch \& Lomb, Inc., 256 F. Supp. 2d 228, 234 (D. Del. 2003) (rejecting the "argument that an 'offer to sell' can only take place if there is also an unlawful [actual or contemplated] sale within the United States" and instead holding that to so require would "make[] the 'offer to sell' language in $\$ 271$ (a) superfluous"). Others contemplate a far narrower reading. See, e.g., Rotec Indus., Inc. v. Mitsubishi Corp., 215 F.3d 1246, 1258-60 (Fed. Cir. 2000) (Newman, J., concurring) (arguing that an offer can be infringing only if the contemplated sale would infringe the patent, and thus that the sale must be contemplated to occur in the United States). A similar narrow interpretation of the analogous United Kingdom Statute, discussed infra note 142, was adopted in Kalman v. PCL Packaging Ltd., [1982] F.S.R. 406, 417-18 (U.K. Patents Ct. 198218 (EWHC (Pat)) (interpreting the prohibition on "offers to dispose of" to required both the offer and the intended disposal of the product to occur in the United Kingdom).

${ }^{95}$ See 35 U.S.C. $\$ 271$ (i)

96 See 5 Donald S. Chisum, Chisum ON PATENTs $§ 16.02$, at 16-9 (2004) (noting that the "offer to sell" language "extends the scope of a patentee's rights to unauthorized promotional activities that fall short of actual sale, making or use"); Morishita, supra note 16, at 911-12 (noting that regardless whether "offer to sell" infringement encompasses offers leading to even foreign, noninfringing sales or only offers contemplating domestic, infringing sales, patent protection will be strengthened); Garlepp, supra note 16, at 317 (suggesting that congressional intent in conforming with TRIPs was to "recogniz[e] the offering to sell as an exclusive right separate and distinct from the right to sell"); 3D Sys., Inc. v. Aarotech Labs., Inc., 160 F.3d 1373, 1378 (Fed. Cir. 1998) (acknowledging that " $[\mathrm{t}]$ he amendment to $\S 271$ (a) represents a distinct change to the bases for patent infringement").

The extension of patentee rights is agreed upon even by those who posit the very restrictive interpretation that no new cause of action has been created. See Thomas L. Irving \& Stacy D. Lewis, Proving a Date of Invention and Infringement After GATT/TRIPS, 22 AIPLA Q.J. 309, 352 (1994) (arguing that the primary result of the "offer to sell" language is to make "the date of infringement ... reach back to the date of the original offer" so as to enhance damage awards and give the patentee an earlier opportunity to obtain injunctive relief to block a pending sale); Quality Tubing, Inc. v. Precision Tube Holdings Corp., 75 F. Supp. 2d 613, 623-24 (S.D. Tex. 1999) (arguing that interpreting the "offer to sell" language to give a patentee more than the right to "sue ... for infringement at an earlier stage" would essentially extend the coverage of a U.S. patent to prohibit activities abroad that are not otherwise infringing). 


\section{B. Distinguishing "Offer To Sell" (Infringement) from "Offer" (Contract Law) and "On Sale" (Patentability Bar)}

Two convenient references may be used as guides towards determining what constitutes an infringing "offer to sell." In general, "offer" has acquired a well circumscribed meaning based on centuries of contract law jurisprudence. ${ }^{97}$ In the context of U.S. patent law, there has been extensive interpretation of the "on sale" patentability bar, ${ }^{98}$ culminating in Pfaff $v$. Wells Electronics, in which the Supreme Court decisively addressed this statutory language. ${ }^{99}$ However, distinguishing features of the infringement context render both metrics partially inapposite to the task of defining the parameters of an infringing "offer to sell."

Using an economic rationale, the narrow contractual meaning of "offer" is inadequate to protect the economic rights of a patentee in her invention. ${ }^{100}$ A broader lay meaning of "offer" would better protect a patentee from commercial activity having the potential to erode the market price for the patented article since it would encompass promotional activities more akin to commercialization or marketing (rather than sale per se) of the invention such as advertisements, so-

\footnotetext{
${ }^{97}$ See, e.g., FARNSWORTH, supra note $48, \S 3.3$, at 112-13 (defining an offer as "a manifestation to another of assent to enter into a contract" through which "the offeror thus confers upon the offeree the power to create a contract"). But see RICHARD A. LORD, WILLISTON ON CONTRACTS $§ 4: 7$ (4th ed. 1990) ("Though the general rule is that an advertisement, circular, price list, quotation or the like is not an offer, there is no doubt that a positive offer may be made even by an advertisement or other similar general notice.").

${ }_{98}^{9}$ See 35 U.S.C. $\$ 102$ (b) (2000) ("A person shall be entitled to a patent unless ... the invention was ... on sale in this country, more than one year prior to the date of application for patent ....").

${ }^{99} 525$ U.S. 55, 67 (1998). The current application of the "on sale" bar is governed by the interpretation of Pfaff, which requires both that "the product must be the subject of a commercial offer for sale" and that "the invention must be ready for patenting" by virtue of either actual or constructive reduction to practice. Id. The rule has been applied by the CAFC in several cases, including: Allen Eng'g Corp. v. Bartell Indus., Inc., 299 F.3d 1336, 1352-55 (Fed. Cir. 2002), EZ Dock v. Schafer Sys., Inc., 276 F.3d 1347, 1351-52 (Fed. Cir. 2002), and Group One, Ltd. v. Hallmark Cards, Inc., 254 F.3d 1041, 1046-59 (Fed. Cir. 2001).

${ }^{100}$ See FARNSWORTH, supra note $48, \S 3.3$, at 112-13 (setting forth a definition of "offer" as applied in contract law).
} 
licitations, mailings, and proposals. ${ }^{101}$ It is these activities-and not just formal contractual offers-that have the potential, under the rubric of "offers for sale," to cause detrimental erosion of a patentee's exclusive right. ${ }^{102}$

By contrast, the narrowest suggested interpretation of the term, that "offer to sell" infringement functions as a cause of action merely to advance the date at which a patentee may sue to enjoin a putatively infringing sale, ${ }^{103}$ is so limited that it would practically eviscerate the statute, rendering it nearly incapable of preventing the economic consequences of activities conducted in preparation for a such a sale. ${ }^{104}$ Under this limited interpretation, an offer to sell incapable of resulting in an infringing sale would not be considered infringement despite the detrimental market impact that may accrue to the patentee. $^{105}$

Similarly, there are substantial impediments to drawing a straightforward analogy between the "on sale" bar of $\S 102$ (b) and the "offered for sale" prohibition of $\S 271(\mathrm{a})$. The two statutes serve differ-

${ }^{101}$ See Holbrook, Liability for the "Threat of a Sale," supra note 16, at 798 (positing that price erosion due to competition is the main deleterious economic consequence of infringing offers for sale, and arguing that the United States should adopt a broad interpretation of "offer to sell" to "more appropriately protect the patentee's interests"); Morishita, supra note 16, at 909 (contrasting "the legal definition of 'offer'" with "the lay meaning that equates an offer to a proposal or solicitation [and that] would probably include advertisements and promotional efforts").

${ }^{102}$ See Holbrook, Liability for the "Threat of a Sale," supra note 16, at 798 ("Price erosion can result from competitor activity that falls short of a formal commercial offer.").

${ }^{103}$ See Irving \& Lewis, supra note 96, at 352 ("The main consequence of requiring an actual sale during the patent term in order to make the offer for sale an act of infringement appears to be that the date of infringement will reach back to the date of the original offer."); see also Quality Tubing, Inc. v. Precision Tube Holdings Corp., 75 F. Supp. 2d 613, 623-24 (S.D. Tex. 1999) ("The language of the statute and the cases make it clear that expanding the list of infringing activities ... to include an 'offer to sell' rather than merely a 'sale' protects a patent holder at an earlier stage of infringing activity.").

${ }^{104}$ See Holbrook, Liability for the "Threat of a Sale," supra note 16, at 798 (suggesting that a narrow interpretation of "offer to sell" would not protect patent holders from price erosion).

${ }^{105}$ A tangible example of such a scenario would be a variation on the facts of Rotec Industries, Inc. v. Mitsubishi Corp., 215 F.3d 1246, 1249-50 (Fed. Cir. 2000), discussed in Part II.C, where an offer to sell a patented article indisputably occurs in the United States but the elements of the actual sale (i.e., delivery and payment) are contemplated to occur in a foreign country. A narrow interpretation relying on actual sale is also problematic since it runs counter to the plain text and structure of $\S 271$ (a), which places "offer to sell" on par with "make, use, and sell," enumerating each as a distinct infringing activity. See Sulkis, supra note 16, at 1124-26 (arguing that any other "interpretation ... violates the standard maxim of statutory construction that an interpretation of a statute should not render any other portion of the statute meaningless"). 
ent, albeit complementary, policies ${ }^{106}$ that arise out of the constitutional mandate " $[\mathrm{t}]$ o promote the Progress of Science and useful Arts, by securing for limited Times to ... Inventors the exclusive Right to their ... Discoveries." ${ }^{\text {"107 }}$ Further, such a narrow construal of "offer for sale" in $\S 271(\mathrm{a})^{108}$ ignores the larger context of the "on sale" bar among the other conditions for loss of right to patent prescribed in $\S$ 102(b), an error in focus that both commentators and the Federal Circuit have made. ${ }^{109}$

The Federal Circuit has recognized that the policy reasons for the "on sale" bar are generally geared towards promoting dissemination of inventions, and include allowing inventors a grace period to evaluate the commercial potential of an invention while preventing patentees from unreasonably extending the time-span of exclusivity, "encouraging prompt and widespread disclosure of inventions to the public, [and] discouraging the removal of inventions from the public domain." 110 This provision acts as the "stick" with regard to the inventor, assuring that the invention will enter the public domain as soon as is reasonably possible, either by forfeiture of patent rights or by expiration of the patent, and serves to temporally circumscribe an inventor's rights. ${ }^{111}$

By contrast, the "offer to sell" infringement protection is directed at promoting investment in the commercialization of inventions. ${ }^{112}$

${ }^{106}$ Rotec, 215 F.3d at 1255 n.3 (contrasting the policy rationales underlying the "on-sale" prohibition with "offer to sell" infringement liability). Contra Holbrook, Liability for the "Threat of a Sale," supra note 16, at 777-78 (arguing that the rationales are economically the same because although one ostensibly limits the patent holder's enjoyment of the patent's value to the patent term (plus the grace period) and the other limits the rights of others to enjoy that value, the value protected by both is the same).

${ }^{107}$ U.S. CONST. art. $1, \S 8, \mathrm{cl} .8$.

108 See supra note 99 (discussing the interpretation of an offer under the "on sale" patentability bar).

${ }^{109}$ See, e.g., Holbrook, Liability for the "Threat of a Sale," supra note 16, at 780-81 (failing to recognize that $\S 102$ (b) also bars a patent if the invention is described in a printed publication more than one year before an application for patent is filed); see also Rotec, 215 F.3d at 1254-56 (comparing the "offered for sale" prohibition of $\S$ 271 (a) with only the "on sale" bar portion of $\$ 102(\mathrm{~b})$ ).

${ }_{110}$ 3D Sys., Inc. v. Aarotech Labs., Inc., 160 F.3d 1373, 1379 n.4 (Fed. Cir. 1998).

${ }^{111}$ See Pfaff v. Wells Elecs., Inc., 525 U.S. 55, 64 (1998) ("Consistent with [the constitutional mandate], $\$ 102$ of the Patent Act serves as a limiting provision, both excluding ideas that are already in the public domain from patent protection and confining the duration of the monopoly to the statutory term.").

${ }^{112}$ See Johnson \& Johnson Assocs., Inc. v. R.E. Servs. Co., 285 F.3d 1046, 1071 (Fed. Cir. 2002) ("Discovery of and commercialization of new things is notoriously riskladen, yet it is the inventor and the innovator, those whose ingenuity and ambition create new things while taking the risk of loss, who provide the basis of industrial advance and economic growth."); In re Alappat, 33 F.3d 1526, 1571 (Fed. Cir. 1994) (rea- 
This provision acts as the "carrot" with regard to the inventor, assuring that money spent manufacturing, promoting, and commercializing the patented invention will benefit only the inventor, by prolonging the first-mover advantage and preventing copiers from free-riding on the inventor's investments for a predictable time period. ${ }^{113}$

The statutory language surrounding the "on sale" bar defines other activities, in addition to a commercial offer for sale, that may create an absolute bar to patentability. A printed publication antedating the patent application by one year or more is an equally effective patentability bar, ${ }^{114}$ as long as it conveys the invention with sufficient particularity that a person having ordinary skill in the art is thereby placed in possession of the invention. ${ }^{115}$ It is established that "printed publication" is a "unitary concept," ${ }^{, 16}$ defined not by the medium of publication ${ }^{117}$ but by whether there is "sufficient proof of its dissemi-

soning that research and development expenditures are only valuable to the public if "there are suitable incentives to invest in commercialization [, i.e.,] a chance of reasonable profits from risk taking" (quoting Irving S. Shapiro, Chairman, E.I. du Pont de Nemours \& Co., Technology's Decline: America's Self-Made Paradox (Jan. 22, 1979), in 45 VITAL SPEECHES OF THE DAY 360, 364 (1979) (internal quotation marks omitted)) ).

${ }^{113}$ See King Instruments Corp. v. Perego, 65 F.3d 941, 960 (Fed. Cir. 1995) ("Congress made the policy choice that the 'carrot' of an exclusive market for the patented goods would encourage patentees to commercialize the protected inventions so that the public would enjoy the benefits of the new technology during the patent term in exchange for granting a limited patent monopoly.").

${ }^{114}$ In addition to barring patent protection for an invention that was on sale in the United States for more than one year prior to filing the patent application, $\S 102$ (b) bars entitlement to a patent if "the invention was patented or described in a printed publication" anywhere in the world, also with the same one year grace period. 35 U.S.C. $\$ 102(b)(2000)$.

${ }^{115}$ Pfaff, 525 U.S. at 67-68; see also The Telephone Cases, 126 U.S. 1, 536 (1888) (holding that an invention can be sufficiently reduced to practice in writing if the inventor "describes his method with sufficient clearness and precision to enable those skilled in the matter to understand what the process is [and] points out some practicable way of putting it into operation").

${ }^{116}$ In re Wyer, 655 F.2d 221, 226 (C.C.P.A. 1981) (advising that the phrase is not to be parsed to analyze "printed" and "publication" independently).

117 This is true regardless "whether information is printed, handwritten, or on microfilm or a magnetic disc or tape, etc." Id. at 227. Additionally, because "[t]he statutory phrase 'printed publication' has been interpreted to give effect to ongoing advances in the technologies of data storage, retrieval, and dissemination," a wide variety of nontraditional publications qualify. In re Hall, 781 F.2d 897, 898 (Fed. Cir. 1986). Even Internet web pages, sales brochures, pamphlets, and instruction booklets qualify as printed publications, at least when they are generally accessible to some segment of the public, regardless of the means or the number of persons who have access. See Popeil Bros., Inc. v. Schick Elec., Inc., 494 F.2d 162, 166 (7th Cir. 1974) ("To constitute a printed publication for purposes of the publication bar, all that is required is that the document in question be printed and so disseminated as to provide wide pub- 
nation or that it has otherwise been available and accessible to persons concerned with the art to which the document relates." 118

Therefore, notwithstanding the prevailing interpretation of the "on sale" portion of the $\S 102$ (b) language, the patentability bar statute encompasses many activities that may be categorized as advertising, marketing, soliciting, and commercializing-the precursors to "offers" under contract law that are not sales per se but are intended to generate sales. Since the purpose of $\S 271$ (a) is to provide a complementary economic incentive to $\S 102$ (b), "offer to sell” infringement should also encompass such nascent sales activities. Viewing the "on sale" portion of $\S 102$ (b) in its full textual context both leaves undisturbed Pfaff s holding ${ }^{119}$ and remains faithful to the parallels drawn in Rotec, ${ }^{120}$ yet permits a broad interpretation of $\S 271(\mathrm{a})$ that is more conducive to effectively protecting against diminishment of a patentee's exclusive right by pre-sale commercialization activities.

\section{The Federal Circuit's Interpretation of "Offer To Sell"}

Since the addition of "offer to sell" patent infringement, the CAFC has considered only three "offer to sell" cases that had been adjudicated on the merits in district court: Rotec Industries, Inc. v. Mitsubishi Corp., ${ }^{121}$ MEMC Electronic Materials, Inc. v. Mitsubishi Materials Silicon Corp., ${ }^{122}$ and Fieldturf International, Inc. v. Sprinturf, Inc. ${ }^{123}$ In Rotec, the court had its first bona fide opportunity to consider the meaning of

lic access to it." (citing Pickering v. Holman, 659 F.2d 403, 407 (9th Cir. 1972); Deep Welding, Inc. v. Sciaky Bros., Inc., 417 F.2d 1227, 1235 (7th Cir. 1969); Jockmus v. Leviton, 28 F.2d 812, 813 (2d Cir. 1928))).

${ }^{118}$ In re Wyer, 655 F.2d at 226 (quoting Philips Elec. \& Pharm. Indus. Corp. v. Thermal \& Elec. Indus., Inc., 450 F.2d 1164, 1171 (3d Cir. 1971)).

119525 U.S. at 67 (interpreting the $\$ 102$ (b) "on sale" bar as applicable where the product is both "the subject of a commercial offer for sale" and "ready for patenting").

${ }^{120}$ Rotec Indus., Inc. v. Mitsubishi Corp., 215 F.3d 1246, 1254-55 (Fed. Cir. 2000) (relying on Pfaff to analogize the meaning of "offers to sell" in \$271(a) with that of "on sale" in $\S 102(\mathrm{~b})$ ). See infra Part II.C (discussing the Rotec court's application of the Pfaff analysis of the "on sale" bar to interpret "offer to sell" in accordance with contract law).

121215 F.3d 1246, 1248 (Fed. Cir. 2000) (affirming the district court's order granting summary judgment of noninfringement).

${ }^{122} 420$ F.3d 1369, 1382-88 (Fed. Cir. 2005) (affirming the part of the district court's order granting summary judgment in favor of the alleged infringers with respect to direct infringement).

${ }^{123} 433$ F.3d 1366, 1370 (Fed. Cir. 2006) (affirming the district court's order granting summary judgment of noninfringement). 
the statutory language. ${ }^{124}$ In $M E M C$, the court found no evidence of activities occurring in the United States that could constitute an "offer to sell" the patented device, and thus affirmed. ${ }^{125}$ MEMC applied the Rotec test and relied heavily on the analysis in $3 D$ Systems. ${ }^{126}$ Fieldturf cited Rotec but did not rely on it, instead basing its decision on the district court's finding that the product allegedly offered for sale was not the patented product but a noninfringing equivalent. ${ }^{127}$

Rotec involved the allegedly infringing offer for sale of plaintiff Rotec's patented conveyor system to the Chinese government for use in the Three Gorges Dam project on the Yangtze River. ${ }^{128}$ Critical to the resolution of the case was the fact that defendants Mitsubishi, Potain, Johnson, and Tucker ${ }^{129}$ submitted a joint bid proposal to the Chinese government; none of the defendants was a subcontractor and the only sales transaction was to be between the joint bidders and their Chinese government customer. ${ }^{130}$ The district court ultimately granted summary judgment for the defendants ${ }^{131}$ after "finding insufficient evi-

${ }^{124}$ In full recognition of this task, the court devoted extensive discussion to the historical background of the "offer to sell" infringement provision. See Rotec, 215 F.3d at 1253 ("We must still decide, however, what constitutes an 'offer' as that term is used in $§ 271(\mathrm{a})$. .).

${ }^{125} 420$ F.3d at 1377.

${ }^{126}$ See id. at 1376 (citing Rotec and 3D Systems in analyzing what is an "offer to sell" under $\S 271(\mathrm{a})$ ). Because MEMC did not alter the analysis of Rotec or 3D Systems, it will not be considered further in this Comment.

127433 F.3d at 1370. Fieldturf did not change the law as set out in the prior "offer to sell" cases and will not be considered further in this Comment.

${ }^{128}$ Rotec, 215 F.3d at 1248-49. Rotec Industries, an Illinois corporation, held U.S. Patent No. 4,170,291 (filed Mar. 7, 1978) (issued Oct. 9, 1979) covering the conveyor system at issue. $I d$. at 1248. Sale of the patented conveyor system was also alleged; however, since the sale itself occurred abroad, it was not covered by the U.S. patent laws. Rotec Indus., Inc. v. Mitsubishi Corp., 36 F. Supp. 2d 810, 814 (C.D. Ill. 1998); Rotec, 215 F.3d at 1248-49, 1251; see Deepsouth Packing Co. v. Laithram Corp., 406 U.S. 518,531 (1972) ("Our patent system makes no claim to extraterritorial effect.").

${ }^{129}$ Mitsubishi Corporation, a Japanese corporation, and Mitsubishi International, a New York corporation, are referred to collectively as "Mitsubishi." Potain, a French corporation, and Johnson, an Illinois corporation, were jointly working on a conveyor system design and were solicited by Mitsubishi to put in a joint bid to the Chinese government. Rotec, 215 F.3d at 1249. Tucker Associates, an Oregon corporation (operated by Gary Tucker, an individual domiciled in Oregon), was brought in by Johnson as an independent contractor to help prepare the bid. Id.

${ }^{130} I d$. at $1248-50,1255$.

${ }^{131}$ Summary judgment was granted as to Mitsubishi and Tucker. Id. at 1250 . Johnson was dropped from the complaint after filing for bankruptcy, and Potain was dismissed by the district court for lack of personal jurisdiction. Id. at 1249 n.1. 
dence of an offer to sell within the United States," ${ }^{132}$ and Rotec appealed.

Because of the procedural posture of the case, the CAFC focused on the meaning of the statutory language of $\S 271(\mathrm{a})$; the defendants did not dispute that they had offered to sell the invention claimed in the subject patent, but instead argued for summary judgment only on the basis that the offer was not made in the United States. ${ }^{133}$ Therefore, the court recognized that summary judgment would be improper if, as a matter of law, the alleged infringer's "activities in the United States, as would be construed by a reasonable jury, [we] re sufficient to establish an 'offer for sale,' as that phrase is used in $§ 271$ (a).,

The Rotec court embraced an interpretation of "'offer to sell' liability according to the norms of traditional contract analysis," 135 an approach held to be consistent with the recent Pfaff analysis ${ }^{136}$ of the "on sale" bar. ${ }^{137}$ In so doing, the court casually dismissed the broader lay definition applied in 3D Systems, which had encompassed price quotation letters as qualifying "offers to sell" under $§ 271(\mathrm{a}),{ }^{138}$ recognizing, perhaps speciously, that the $3 D$ Systems decision did not benefit from the insight of Pfaff. ${ }^{139}$ Noting the international pedigree of the "offer

${ }^{132} I d$. at 1250. Although substantial activity among the bidders prior to their contract with the Chinese government occurred in the United States, and the defendants did not dispute that an offer to sell was made by the joint bidders to the Chinese government, the district court found that the critical acts of finalizing and presenting the bid proposal, negotiating with the Chinese government, and signing the sales agreement all occurred in China or Hong Kong. Id.

${ }^{133} I d$. at 1251. This is essentially the same argument that prevailed in the district court. See Rotec, 36 F. Supp. 2d at 817 (granting summary judgment for the defendants on the ground that "no genuine issue of fact exists regarding whether an actual 'offer to sell' was made by Defendants in the United States"). An alternative defense may have been based on the contention that the intended sale would not have occurred in the United States, but the district court did not need to reach that issue. Id. at 815 (noting the plaintiff's contention that "while the contract eventually signed provided for procurement and manufacturing to occur in China and Japan, there was a question of fact regarding whether the bid proposal made by Defendants to the Chinese buyer contemplated the manufacture of the conveyor components in the United States").

${ }^{134}$ Rotec, 251 F.3d at 1251.

${ }^{135} I d$. at $1254-55$.

${ }^{136}$ Pfaff, 525 U.S. at 67-68; see also supra notes 98-99 and accompanying text (discussing the "on sale" bar as interpreted in Pfaff) .

${ }^{137}$ Rotec, 215 F.3d at 1254. The CAFC also held the traditional contract meaning of "offer to sell" to be consistent with its earlier analysis of the term "sale or importation" under $\S 337$ of the Tariff Act of 1930 (current version at 19 U.S.C. $\S 1337$ (2000)). Id. at 1255 .

138 3D Sys., Inc. v. Aarotech Labs. Inc., 160 F.3d 1373, 1378-79 (Fed. Cir. 1998); see supra Part I.B (discussing the analysis of "offer to sell" in 3D Systems).

${ }^{139}$ Rotec, 215 F.3d at 1254. 3D Systems was decided two days after Pfaff. 
to sell” provision of $\S 271(\mathrm{a}),{ }^{140}$ the court also briefly considered, and ultimately rejected, ${ }^{141}$ the broader interpretation of the parallel "offer to dispose of" provision in the United Kingdom patent code. ${ }^{142}$

Ultimately, the distinctions between broader and narrower meanings of "offer to sell" did not impact the decision in Rotec, as the plaintiff lost on the facts by failing to show evidence of any communication in the United States between the alleged infringer and a third party

${ }^{140}$ See supra note 1 (detailing the effect of TRIPs on U.S. patent law). It is generally recognized that the U.S. patent laws have no extraterritorial reach. See Deepsouth Packing Co. v. Laitram Corp., 406 U.S. 518, 531 (1972) ("Our patent system makes no claim to extraterritorial effect."); Ortho Pharm. Corp. v. Genetics Inst., Inc., 52 F.3d 1026, 1033 (Fed. Cir. 1995) (emphasizing that "a U.S. patent grants rights to exclude others from making, using and selling the patented invention only in the United States"). Additionally, there is a long tradition of interpreting U.S. patent laws in the federal courts, with patent infringement cases dating to the early years of the nation. E.g., Reutgen v. Kanowrs, 20 F. Cas. 555 (C.C.D. Pa. 1804) (No. 11,710) (cited by HerberT F. SChWARTZ, PATENT LAW AND PRACTICE 233 (4th ed. 2003), as the first patent case tried to a jury in the United States); Morse v. Reed, 17 F. Cas. 873 (C.C.D.N.Y. 1796) (No. 9860). Nevertheless, because international harmonization of the multitude of national patent laws is arguably an underlying purpose of TRIPs, it is not entirely implausible that U.S. courts should consider the interpretation of similar provisions abroad. Compare Lisa B. Martin \& Susan L. Amster, International Intellectual Property Protections in the New GATT Accord, J. PROPRIETARY RTS., Feb. 1994, at 9, 9 (hailing TRIPs as "a far-reaching plan that attempts to strengthen and harmonize the standards of intellectual property protection offered throughout the world"), and Adam Isaac Hasson, Note, Domestic Implementation of International Obligations: The Quest for World Patent Law Harmonization, 25 B.C. INT'L \& COMP. L. REV. 373, 388 (2002) (concluding that TRIPs, "while imperfect, has taken unprecedented steps towards the harmonization of world patent law"), with John F. Duffy, Harmony and Diversity in Global Patent Law, 17 BERKELEY TECH. L.J. 685, 686 (2002) (questioning the merits of complete international harmonization of patent law).

${ }^{141}$ See Rotec, 215 F.3d at 1253 (declaring that "we must ultimately decide this issue as a matter of United States law"). Unless the Federal Circuit reconsiders the value of international case law in construing the "offer to sell" statutory language, any reasoning relying on it is probably consigned to dissenting opinions and law review articles as a theory with strong rhetorical but weak practical value.

${ }^{142}$ The U.K. Patents Act provides for infringement liability when a person "makes, disposes of, offers to dispose of, uses or imports" a patented product and the prohibited act is done in the U.K. "while the patent is in force." Patents Act, 1977, c. 37, pt. I, $\S 60$ (1) (a) (Eng.). Gerber Garment Technology Inc. v. Lectra Systems Ltd., [1995] 13 R.P.C. 383, 411 (U.K. Patents Ct.), broadly interpreted an infringing "offer to dispose of" to extend beyond the bounds of traditional contract law. Indeed, recognizing that this aspect of English patent law derives from the Community Patent Convention, the Gerber court held that " $[\mathrm{a}]$ party who approaches potential customers . . . by advertisement saying he is willing to supply a machine, terms to be agreed, is offering it" and that so "disturbing the patentee's monopoly" is infringement. Id. at 412. The Community Patent Convention to which Gerber referred, embodied in Council Directive 89/695/ EEC, Agreement Relating to Community Patents, art. 25(a), 1989 O.J. (L 401) 1, 14, provides that the proprietor of a Community patent has the right to prevent third parties "from making, offering, putting on the market or using" the patented product without the proprietor's consent. 
resulting in "commercial detriment [to] the rightful patentee." ${ }^{143}$ Therefore, there was no infringing "offer to sell" under $§ 271$ (a). The resolution of Rotec on the merits based on the absence of an "offer to sell" is in stark contrast to the analyses of procedural motions in $3 D$ Systems and HollyAnne, which applied the results of their respective substantive "offer to sell" analyses only to resolve the propriety of the assertion of personal jurisdiction over the defendants. ${ }^{144}$

Unfortunately, there is insufficient information in the Rotec district court opinion to determine the basis upon which personal jurisdiction existed over the defendants; the court merely noted that a defendant domiciled in France was dismissed for lack of personal jurisdiction while defendants domiciled in Japan and Oregon were held to account. ${ }^{145}$ SD Systems and HollyAnne cast uncertainty upon whether the CAFC in Rotec would have exercised specific personal jurisdiction over any of the defendants based only upon the activities within the United States that were at issue in the case. ${ }^{146}$

\section{KEEPING THE SUbSTANTIVE “OFFER TO SELL" INFRINGEMENT ANALYSIS DISTINCT FROM THE PERSONAL JURISDICTION DETERMINATION}

Meaningful enforcement of "offer to sell" patent infringement requires that a patentee be able to obtain personal jurisdiction over an alleged infringer based on the allegedly infringing activities in the forum. In many situations, such enforcement is contingent upon whether the in-forum contacts needed to justify the exercise of personal jurisdiction are distinguishable from the activities needed to constitute an infringing "offer to sell."

Therefore, the question posed in this Comment may be viewed from two perspectives. First, in what cases could an infringing "offer to sell" exist where personal jurisdiction would not legitimately be authorized? Conversely, in what cases could personal jurisdiction be proper where there is not an infringing "offer to sell"? The second

\footnotetext{
${ }^{143}$ Rotec, 215 F.3d at 1255 . Simply put, because $\S 271$ (a) requires an "offer[] to sell ... within the United States," an offer to sell occurring abroad lacks one of the required elements of infringement. 35 U.S.C. $\$ 271$ (a) (2000).

${ }^{144}$ See supra Part I.B (discussing the interpretation of "offer to sell" in $3 D$ Systems and HollyAnne).

${ }^{145}$ Rotec Indus., Inc. v. Mitsubishi Corp., 36 F. Supp. 2d 810, 812 (C.D. Ill. 1998). Perhaps sufficient in-forum contacts existed for the exercise of general personal jurisdiction over each remaining defendant.

${ }^{146}$ See supra Part I.B (discussing the Federal Circuit's adjudication of personal jurisdiction in the context of "offer to sell" infringement actions in 3D Systems and HollyAnne).
} 
prong of the Akro test ${ }^{147}$ renders the first scenario a virtual impossibility; an alleged "offer to sell" qualifying under the statutory meaning of $\S 271$ (a) will almost certainly also satisfy the "arises out of or relates to" criterion for personal jurisdiction. ${ }^{148}$

On the other hand, there should be many cases where personal jurisdiction can legitimately be found based on allegedly purposefully directed "offer to sell" activities but where there is ultimately no infringing "offer to sell" under $\S 271(\mathrm{a}) .{ }^{149}$ These cases provide the driving reason for keeping the two determinations distinct. If the "offer to sell" provision of $\S 271$ (a) is to have any teeth-any real power to deter infringement-it is essential that courts take jurisdiction of such cases based on reasonable allegations of "offers to sell" without first having to determine substantively whether the statutory language is met. $^{150}$

147 See supra note 34 and accompanying text.

${ }^{148}$ Perhaps an exception could occur in a reasonableness of due process situation where the alleged "offer to sell" is masked from the defendant by virtue of the defendant being a subvendor to the party making the actual offer (and thus fails on the third Akro prong). Cf. Asahi Metal Indus. Co. v. Superior Court, 480 U.S. 102, 114 (1987) (holding that the assertion of jurisdiction over an alien defendant would be unreasonable under a due process analysis, given the severe burden on the defendant and the slight interests of the plaintiff and the forum in pursuing the litigation). Ecological Systems Technology v. Aquatic Wildlife Co., 142 F. Supp. 2d 122 (D. Mass. 2000), may be such a case. The primary defendant, Aquatic, suffered a default judgment for failure to plead or otherwise defend. Id. at 123. However, the secondary defendant, U.S. Aquarium, successfully moved to dismiss for lack of personal jurisdiction on the basis that it was simply a contract manufacturer who "had no knowledge of any infringement and ceased manufacturing the patented aquarium system [for Aquatic] upon" learning of the allegation. Id. It may even be dubious to term this type of case an exception since the disconnect is that the actual offer was made by a party other than the one over whom personal jurisdiction is sought.

Another exception may occur if the alleged "offer to sell" activity could be deemed not purposefully directed to the forum as required by the first Akro prong. However, as is discussed in Part III.B, the first and third prongs of Akro are really two sides of the same coin-the underlying reason for the purposeful availment requirement is to evaluate the reasonableness of the assertion of personal jurisdiction.

${ }^{149}$ Part III.A addresses some cases that may fall into this category. In particular, see infra notes 154-58 and accompanying text (discussing cases that differentiated between the personal jurisdiction and "offer to sell" determinations) and notes 164-81 and accompanying text (discussing cases where personal jurisdiction may have been proper but was denied due to conflation of the two analyses).

${ }^{150}$ Indeed, the CAFC recognized in Beverly Hills Fan Co. v. Royal Sovereign Corp., 21 F.3d 1558, 1565 (Fed. Cir. 1994), that when "[t] he cause of action for patent infringement is alleged to arise out of [the defendant's in-forum] activities[, $\mathrm{n}] \mathrm{o}$ more is usually required to establish specific jurisdiction." 


\section{A. Mixed Decisions in the District Courts}

The lack of clarity in the "offer to sell" infringement doctrine engendered by the Federal Circuit analysis in 3D Systems, HollyAnne, and Rotec has rippled down to create disparate approaches in district court decisions. There are at least three categories of "offer to sell" decisions based on motions to dismiss for lack of personal jurisdiction: those wisely avoiding a substantive determination of whether the alleged activities constitute an infringing "offer to sell"; ${ }^{151}$ those harmlessly conflating the issues, finding the alleged activities sufficient for both infringement and personal jurisdiction purposes; ${ }^{152}$ and those conflating the issues and dismissing cases that probably should have survived to be adjudicated, even if those cases ultimately would have progressed no farther than summary judgment disposition on the merits. ${ }^{153}$

Avoiding the substantive "offer to sell" determination in deciding on the proper exercise of personal jurisdiction recognizes the importance both of procedural posture and of giving a putatively meritorious suit its day in court. In applying the second prong of the Akro test, ${ }^{154}$ the court in Recycling Sciences International, Inc. $v$. Soil Restoration and Recycling, L.L.C. found that since the actions alleged in the complaint "arise out of or directly relate to [the defendant's in-forum] activities... [,] specific jurisdiction [over the defendant] exists." ${ }^{155}$ Similarly, the court in Wafios Machinery Corp. v. Nucoil Industries Co. recognized the low burden on the plaintiff to make merely a prima facie showing in the face of a motion to dismiss for lack of personal jurisdiction, ${ }^{156}$ denying the defendant's motion to dismiss and instead granting the plaintiff's request for additional discovery on the "offer

${ }^{151}$ See, e.g., Wafios Mach. Corp. v. Nucoil Indus. Co., No. 03 Civ. 9865 (RWS), 2004 U.S. Dist. LEXIS 13674, at*16-17 (S.D.N.Y. July 21, 2004); Recycling Scis. Int'l, Inc. v. Soil Restoration \& Recycling, L.L.C., No. 00 C 0311, 2001 U.S. Dist. LEXIS 12989, at *8 (N.D. Ill. Aug. 23, 2001).

${ }^{152}$ See, e.g., Sitrick v. Freehand Sys., Inc., No. 02 C 1568, 2002 U.S. Dist. LEXIS 21140, at *9-16 (N.D. Ill. Oct. 29, 2002); Int'l Truck \& Engine Corp. v. Dawson Int'l Inc., 216 F. Supp. 2d 754, 761-62 (N.D. Ind. 2002); Biometics, L.L.C. v. New Womyn, Inc., 112 F. Supp. 2d 869, 873-74 (E.D. Mo. 2000).

${ }^{153}$ See, e.g., Moldflow Corp. v. Simcon, Inc., 296 F. Supp. 2d 34, 41-44 (D. Mass. 2003); USA Payments, Inc. v. Hotel Ramada of Nev., No. C-01-1450 VRW, 2001 U.S. Dist. LEXIS 9493, at*7-8 (N.D. Cal. June 21, 2001).

${ }_{154}$ See supra note 34 and accompanying text.

1552001 U.S. Dist. LEXIS 12989, at *8, denying reconsideration of Recycling Scis. Int'l, Inc. v. Soil Restoration and Recycling, L.L.C, 159 F. Supp. 2d 1095 (N.D. Ill. 2001).

${ }^{156}$ See supra notes 43-44 and accompanying text (reviewing the procedural burdens involved in a motion to dismiss for lack of personal jurisdiction). 
to sell" issue. ${ }^{157}$ Presumably, on rehearing, the plaintiff will have the burden of showing by a preponderance of the evidence that the Akro three-prong test is satisfied.

Conflating the personal jurisdiction and substantive "offer to sell" issues is doctrinally problematic, but when a court ultimately declines to dismiss for lack of personal jurisdiction, the effects of the error are ameliorated for the particular case at hand. The court in International Truck $\mathcal{E}$ Engine Corp. v. Dawson International Inc. reached a bit too far, falling into the trap set by the $3 D$ Systems analysis of the second Akro prong, ${ }^{159}$ yet held that personal jurisdiction existed because the defendant's activities qualified as an "offer to sell" from which the cause of action arose. ${ }^{160}$ Following the same line of reasoning, the holding of Sitrick v. Freehand Systems, Inc. hinged on the critical second Akro prong issue of whether the defendant's in-forum activities constituted a substantive "offer to sell" under $\S 271(\mathrm{a}){ }^{161}$ In Biometrics, L.L.C. $v$. New Womyn, Inc., the court held that the second Akro prong was satisfied, in part because the "defendants' Internet web site constitute[d] an offer to sell" since it "include[d] a detailed description of the product and its price" and was moderately interactive. ${ }^{162}$ In all three cases, a well pleaded alleged infringing "offer to sell" nominally arising from or related to the in-forum activities should have been enough for

${ }^{157}$ No. 03 Civ. 9865, 2004 U.S. Dist. LEXIS 13674, at *16-17 (S.D.N.Y. July 21, 2004).

${ }^{158}$ Supra notes 33-35, 43-44 and accompanying text.

159 See supra notes 61-67 and accompanying text (discussing the 3D Systems analysis of the second prong of the Akro test).

${ }^{160} 216$ F. Supp. 2d 754, 761-62 (N.D. Ind. 2002).

${ }^{161}$ No. 02-C-1568, 2002 U.S. Dist. LEXIS 21140, at *9-16 (N.D. Ill. Oct. 29, 2002). The court ultimately decided that the "mailing [of] brochures, sample parts, and price quotation letters" met the requirements of an "offer to sell." Id. at *10.

${ }^{162} 112$ F. Supp. 2d 869, 873-74 (E.D. Mo. 2000); cf. Recycling Scis. Int'l, Inc. v. Four Seasons Envtl., Inc., No. 03-C-6460, 2004 U.S. Dist. LEXIS 6572, at *6 (N.D. Ill. Apr. 16, 2004) (finding a passive web site insufficient to convey specific personal jurisdiction by way of an offer to sell). The burgeoning topic of Internet-based contacts for purposes of specific personal jurisdiction is largely based on the "sliding scale" of interactivity set forth in Zippo Manufacturing Co. v. Zippo Dot Com, Inc., 952 F. Supp. 1119, 1124-25 (W.D. Pa. 1997). See generally Paul Schiff Berman, The Globalization of Jurisdiction, 151 U. PA. L. REV. 311 (2002); Susan Nauss Exon, A New Shoe Is Needed To Walk Through Cyberspace Jurisdiction, 11 ALB. L.J. SCI. \& TECH. 1 (2000); Felix C. Pelzer, Unchartered Territory: Personal Jurisdiction in the Internet Age, 51 S.C. L. REV. 745 (2000); Katherine C. Sheehan, Predicting the Future: Personal Jurisdiction for the Twenty-First Century, 66 U. CIN. L. REV. 385 (1998); Frederick H. Bicknese, Comment, Websites and Personal Jurisdiction: When Should a Defendant's Internet Selling Activities Subject It to Suit in a Plaintiff-Buyer's State?, 73 TEMP. L. REV. 829 (2000); Daniel Steuer, Comment, The Shoe Fits and the Lighter Is Out of Gas: The Continuing Utility of International Shoe and the Misuse and Ineffectiveness of Zippo, 74 U. COLO. L. REV. 319 (2003). 
each respective court to exercise subject matter and personal jurisdiction without needing to reach the substantive issue of whether in fact there was an "offer to sell." "163

More troubling are the cases where personal jurisdiction may have been proper but was denied by courts not confining their assessments to the matter presented in the motion to dismiss. In Moldflow Corp. $v$. Simcon, Inc., the court logically found the first prong of Akro to be satisfied and correctly enunciated the standard for the second prong of Akro as requiring the "plaintiffs [to] make a prima facie showing" that their claim "arises out of or relates to" the defendant's in-forum contacts. ${ }^{164}$ Surprisingly, the court then launched into a detailed exploration of the meaning of the "offer to sell" language of $\S 271$ (a) and whether the alleged acts fell within that meaning. ${ }^{165}$ After first acknowledging that under the $3 D$ Systems analysis of the second Akro prong $^{166}$ the plaintiff's case would survive the lack of personal jurisdiction motion, ${ }^{167}$ the court wholeheartedly embraced the Rotec approach $^{168}$ that was hatched in an entirely different procedural context. ${ }^{169}$ Then, latching onto the "on sale" bar analogy ${ }^{170}$ and the requirement that the "invention [be] the subject of a commercial offer for sale" as understood in traditional contract law, ${ }^{171}$ the court determined that the plaintiffs had failed to satisfy the second Akro prong and declined to take jurisdiction of the case. ${ }^{172}$

In analysis reminiscent of HollyAnne, ${ }^{173}$ the court in USA Payments, Inc. v. Hotel Ramada of Nevada dismissed for lack of personal jurisdic-

${ }^{163}$ See Christianson v. Colt Indus. Operating Corp., 486 U.S. 800, 808-09 (1988) (stating that the well-pleaded complaint rule applies to 28 U.S.C $§ 1338$ (a) jurisdiction over patent cases in the same manner as it has long been held to apply to 28 U.S.C. $\S 1331$ federal question cases).

164296 F. Supp. 2d 34, 41 (D. Mass. 2003).

${ }^{165} I d$. at $41-44$.

${ }^{166}$ See supra notes 60-61 and accompanying text.

167296 F. Supp. 2d at 41-42.

168 See supra notes -37 and accompanying text.

169296 F. Supp. 2d at 42-43 (distinguishing 3D Systems and choosing to follow Rotec)

${ }^{170}$ See supra notes 135-37 and accompanying text (explaining the Rotec application of $P f a f f)$.

296 F. Supp. 2d at 43 (quoting Group One, Ltd. v. Hallmark Cards, Inc., 254 F.3d 1041, 1047 (Fed. Cir. 2001), and citing Elan Corp., PLC v. Andrx Pharm., Inc., 272 F. Supp. 2d 1325, 1338-40 (S.D. Fla. 2002), for post-Pfaff elaboration of the "on sale" bar analysis).

${ }^{172} I d$. at 43-45.

${ }^{173}$ See supra notes 83-84 and accompanying text (discussing the Federal Circuit's interpretation of the meaning of "offer to sell" in HollyAnne). 
tion, holding that an "offer to use an allegedly infringing product" does not constitute an "offer to sell" under $§ 271(\mathrm{a}) .{ }^{174}$ Besides ignoring the fact that all of the claims of the subject patent covered a method and not a product, ${ }^{175}$ the court looked for more than was required to meet the second prong of Akro and failed to find it. The court essentially admitted that the cause of action arose out of the defendant's purposefully directed activities in the forum, ${ }^{176}$ activities by which the defendant derived a financial benefit and received the "protection of [the] laws" of the forum, ${ }^{177}$ but dismissed anyway based on its premature substantive finding. ${ }^{178}$ As a result, the patentees in these two cases were effectively prevented from having their colorable claims adjudicated on the merits with the benefit of discovery ${ }^{179}$ and other evidentiary devices afforded by a trial. ${ }^{180}$ Instead their cases were dismissed for essentially substantive reasons, cloaked in the guise of procedural grounds, based only on the preliminary record of the pleadings and motion briefs. ${ }^{181}$

\section{B. Effective "Offer To Sell" Infringement Liability Requires a Different Analysis}

The protection of patent rights requires that a patentee be able to hale an alleged infringer into court where a substantive statutory in-

${ }^{174}$ No. C-01-1450 VRW, 2001 U.S. Dist. LEXIS 9493, at *8 (N.D. Cal. June 21, 2001).

${ }^{175}$ See U.S. Patent No. 6,081,792 (filed Jan. 15, 1998) (issued June 27, 2000).

${ }^{176}$ USA Payments, 2001 U.S. Dist. LEXIS 9493, at *7 ("To be sure, plaintiff has demonstrated that defendant affirmatively markets and promotes the [alleged infringing method and product] to [in-forum] residents through newspaper advertisements, direct mailings and other programs directed at [the forum].”).

${ }^{177}$ Hanson v. Denckla, 357 U.S. 235, 253 (1958).

178 USA Payments, 2001 U.S. Dist. LEXIS 9493, at*7-8. Unfortunately, the court construed the law in a manner that would make it impossible to "offer to sell" a patented method, instead characterizing such an offer as an "offer to use." $I d$. at *8. In fact, the court seemed unable to conceptualize that a method can be patented, repeatedly referring to the invention as a "system" and a "product." See, e.g., id. at *7-8 ("An offer to use an allegedly infringing product, by itself, does not constitute patent infringement." (emphasis added)).

${ }^{179}$ See generally FED. R. CIV. P. 26, 30-36.

${ }^{180}$ See generally FED. R. CIV. P. 43, FED. R. EvID. 101-1103. Consider also the potential impact of the availability of a jury trial under FED. R. CIV. P. 38 per the Eighth Amendment, as opposed to a preliminary disposition by a judge under FED. R. CIV. P. 12(b) (2), which allows a pleader to move to dismiss for "lack of jurisdiction over the person."

${ }^{181}$ See generally FED. R. CIV. P. 7, 8, 12. 
quiry can occur. ${ }^{182}$ Toward that end, there must be a viable set of criteria by which a court can exert personal jurisdiction over an alleged defendant based solely on the purportedly infringing acts occurring within the forum. In the wake of International Shoe $v$. Washington, ${ }^{183}$ the fundamental specific personal jurisdiction examination hinges on due process-whether the exercise of such jurisdiction would be fair and reasonable, that is, whether a defendant purposefully availed herself of the laws of the forum and could have anticipated being subjected to a suit there based on her in-forum activities. ${ }^{184}$ Unfortunately, in devising its own version of the test in $A k r o,{ }^{185}$ the CAFC constructed a framework that diverts the primary focus of the test from the basic due process issue to a particular yardstick by which due process is to be measured, that of a nexus between the in-forum activities on which specific jurisdiction hangs and the cause of action sought to be tried. $^{186}$

In the creation and application of its test for specific personal jurisdiction, the Federal Circuit-bringing along many district courts who have followed its lead-has lost sight of the origins of its test. Typically, the personal jurisdiction inquiry consists of two steps: inquiring whether the long-arm statute of the forum reaches the defendant by virtue of activities within the forum, and then examining whether the exercise of the resultant jurisdiction comports with due process. ${ }^{187}$ The key to the problem identified in this Comment is that

${ }^{182}$ As with any statutorily created private cause of action, the means for individual enforcement of rights under the patent infringement statute is via civil suit. See 35 U.S.C. $\$ 281$ (2000) ("A patentee shall have remedy by civil action for infringement of his patent.").

${ }^{183} 326$ U.S. 310 (1945).

184 BORN, supra note 32, at 74-76; see also Burger King Corp. v. Rudzewicz, 471 U.S. $462,475$ (1985) (" $\mathrm{I}] \mathrm{t}$ is essential in each case that there be some act by which the defendant purposefully avails itself of the privilege of conducting activities within the forum State, thus invoking the benefits and protections of its laws."); World-Wide Volkswagen Corp. v. Woodson, 444 U.S. 286, 297 (1980) (“[T] he defendant's conduct and connection with the forum State are such that he should reasonably anticipate being haled into court there.").

${ }_{185}$ Supra notes 33-35 and accompanying text.

${ }^{186}$ See Akro Corp. v. Luker, 45 F.3d 1541, 1546-47 (Fed. Cir. 1995) (examining the defendant's "purposefully directed activities" in the forum and "their relationship to the cause of action").

${ }^{187}$ See BORN, supra note 32, at 67-68 (illuminating the critical distinction between two separate requirements for a court to exercise personal jurisdiction: there must be a legislative grant of authority, and the "exercise of jurisdiction pursuant to [that grant] must be consistent with the due process clause of the U.S. Constitution"); see also Burger King, 471 U.S. at 463-64, 471-78 (discussing reasons why a forum may exercise personal jurisdiction over a nonresident within the Due Process Clause, after ac- 
the CAFC's second Akro prong, the "arises out of or relates to" criterion, has its genesis in the first step (i.e., the reach of the long-arm statute) of the conventional inquiry. ${ }^{188}$ In the opening sentence of Burger King, cited in Akro as the origin of the "relationship to the cause of action" prong, ${ }^{189}$ the Court propounded that " $[\mathrm{t}]$ he State of Florida's long-arm statute extends jurisdiction [over a person] so long as the cause of action arises from [the alleged in-forum activities]."

The Federal Circuit mixed up the personal jurisdiction analysis in Akro, inserting an emancipated manifestation of the conventional long-arm step as a second prong sandwiched between the first and third prongs that each address different aspects of the due process step. ${ }^{191}$ In doing so, the CAFC divorced from its roots in the long-arm statutes the idea that the cause of action must bear a relationship to

knowledging that the Florida long-arm statute was sufficiently broad to permit jurisdiction over the defendant); Helicopteros Nacionales de Colombia v. Hall, 466 U.S. 408, 412-15 (1984) (evaluating whether a foreign corporation's activities had sufficient minimum contacts with the forum state to comply with the Due Process Clause and noting that the Texas long-arm statute reaches to the limits of Fourteenth Amendment Due Process); Shaffer v. Heitner, 433 U.S. 186, 207-12 (1977) (analyzing the relationship between "the defendant, the State, and the litigation" in the context of the Due Process Clause).

${ }^{188}$ Although 28 U.S.C. $\$ 1338$ (a) provides for exclusive subject matter jurisdiction over patent matters in the federal courts, it does not confer personal jurisdiction via FED. R. CIV. P. 4(k) (1) (D). It is unclear whether service of process would be effective in this context under FED. R. CIV. P. 4(k) (2), which provides that "serving a summons or filing a waiver of service is also effective, with respect to claims arising under federal law, to establish personal jurisdiction over the person of any defendant who is not subject to the jurisdiction of the courts of general jurisdiction of any state," a condition that appears to be met due to the exclusivity of federal jurisdiction in patent cases. Regardless, the Federal Circuit analyzes these cases under the long-arm statute of the state in which the district court hearing the case sits, presumably by way of FED. R. CIV. P. 4(k) (1) (A). See, e.g., 3D Sys., Inc. v. Aarotech Lab., Inc., 160 F.3d 1373, 1377 (Fed. Cir. 1998) (deferring to the California long-arm statute); Akro, 45 F.3d at 1544 (laboring under the Ohio long-arm statute).

${ }^{189}$ Akro, 45 F.3d at 1547.

190471 U.S. at 462, 463-64 (citing FLA. STAT. \$ 48.193(1) (g) (Supp. 1984)). Burger King in turn references Helicopteros, 466 U.S. at 414, which drew its "arises out of" language from the Texas long-arm statute, Tex. REV. CIV. STAT. ANN. art. 2031b (Vernon 1964 \& Supp. 1982-1983). Burger King, 471 U.S. at 472-73. In a poor bit of citation, the Helicopteros Court appears to attribute the statutory language "arises out of" to Shaffer, 433 U.S. at 204, even though the phrase never appears in that case. Helicopteros, 466 U.S. at 414. Instead, the Shaffer analysis focuses on the relatedness of the cause of action, the defendant, and the forum. 433 U.S. at 204.

${ }^{191}$ See Beverly Hills Fan Co. v. Royal Sovereign Corp., 21 F.3d 1558, 1568 (Fed. Cir. 1994) (noting that a due process determination requires both "purposeful minimum contacts" and satisfaction of the "minimum requirements inherent in the concept of fair play and substantial justice" (internal quotation marks omitted) (quoting Asahi Metal Indus. Co. v. Superior Court, 480 U.S. 102, 121-22 (1987))). 
the contacts from which it arises. ${ }^{192}$ Instead, the Federal Circuit has fostered the growth of this criterion into a separate and essential element of the due process step, creating a predicament that significantly impacts the handling of personal jurisdiction motions in "offer to sell" infringement litigation.

It is unarguable that the closeness of the relationship between the cause of action and the defendant's in-forum activities may be an important factor in determining fairness and due process, but whether the cause of action "arises out of" those activities is not the sine qua non of a due process inquiry. ${ }^{193}$ Satisfaction of due process "must depend rather upon the quality and nature of the activity in relation to the fair and orderly administration of the laws which it was the purpose of the due process clause to insure." 194 By wedding itself to the rigid second Akro prong, ${ }^{195}$ the Federal Circuit has turned a factor into a standard and has distorted the due process test to the detriment of plaintiffs-patentees in the case of "offer to sell" infringement suitswho seek to vindicate their statutory and constitutional rights.

Recognizing the origin of the problem-the conflation of issues whereby courts construct a meaning for the statutory "offer to sell" term in the preliminary motion context in which such a determination is not warranted-opens the door to a solution. Because of the binding Federal Circuit precedent created in 3D Systems and HollyAnne, which the district courts in adjudicating patent cases are obligated to follow, ${ }^{196}$ there may be no other choice than to force a sub-

${ }^{192}$ See BORN, supra note 32, at 69 (pointing out that in interpreting state long-arm statutes "it is important to distinguish between statutory interpretation and constitutional analysis").

${ }^{193}$ See Shaffer, 433 U.S. at 204 ("Mechanical or quantitative evaluations of the defendant's activities in the forum [cannot] resolve the question of reasonableness."); Int'l Shoe Co. v. Washington, 326 U.S. 310, 319 (1945) (“[S]o far as those obligations arise out of or are connected with the activities within the state, a procedure which requires [a party] to respond to a suit brought to enforce them can, in most instances, hardly be said to be undue." (emphasis added)).

${ }^{194}$ Int'l Shoe, 326 U.S. at 319.

${ }^{195}$ Supra note 34 and accompanying text.

${ }^{196}$ See Wafios Mach. Corp. v. Nucoil Indus. Co., No. 03 Civ. 9865 (RWS), 2004 U.S. Dist. LEXIS 13674, at*8 (S.D.N.Y. July 21, 2004) ("[W] hen analyzing personal jurisdiction for the purposes of compliance with federal due process, Federal Circuit law ... applies." (quoting 3D Sys., 160 F.3d at 1377)); Moldflow Corp. v. Simcon, Inc., 296 F. Supp. 2d 34, 39 (D. Mass. 2003) ("Because [plaintiff's] underlying claim alleges patent infringement, Federal Circuit law governs the adjudication of [defendant's] motion to dismiss [for lack of personal jurisdiction].”); Sitrick v. Freehand Sys., Inc., No. 02 C 1568, 2002 U.S. Dist. LEXIS 21140, at *5 (N.D. Ill. Oct. 29, 2002) ("Federal Circuit law ... is controlling ... in determining the question of whether the exercise of personal jurisdiction is proper."); Int'l Truck \& Engine Corp. v. Dawson Int'l Inc., 216 F. 
stantive "offer to sell" determination into the analysis of a motion to dismiss for lack of personal jurisdiction, and thus to draw Rotec into the fray. ${ }^{197}$

Such conflation practically obliterates the difference in result between a dismissal for lack of personal jurisdiction (supposedly not on the merits) and a grant of summary judgment for the defendant (on the merits), presenting the defendant with the opportunity to substantively defend the case without subjecting herself to the jurisdiction of the court and officially mounting a defense. This regime significantly impairs a plaintiff's ability to effectively bring an "offer to sell" infringement suit by enabling a dismissal on the pleadings in a way that eviscerates the merits of the case sufficiently to discourage trying again in another forum into which the defendant could be haled into court. Conversely, this regime greatly enhances the ability of a defendant-at least one not subject to general jurisdiction in the forum-to escape liability for offering to sell an infringing article by creating a no-lose situation: a defendant moving to dismiss for lack of personal jurisdiction can assert substantive defenses as part of the motion; if the motion succeeds, the suit probably will not be brought again elsewhere, and if the motion fails, the defendant can reap the benefits of the initial failure to construct an improved substantive defense.

\section{A Possible Solution}

In order to enable a more viable cause of action for "offer to sell" infringement, the Federal Circuit may follow one of two paths. The more radical path, that of abandoning the Akro test ${ }^{198}$ in favor of a more conventional two-step personal jurisdiction determination, ${ }^{199}$

Supp. 2d 754, 757 (N.D. Ind. 2002) ("Federal Circuit law controls the issue of whether a non-resident Defendant accused of patent infringement is subject to personal jurisdiction."); USA Payments Inc. v. Hotel Ramada of Nev., No. C-01-1450 VRW, 2001 U.S. Dist. LEXIS 9493, at *2 (N.D. Cal. June 21, 2001) (holding that since the question of personal jurisdiction with regard to "an alleged out-of-state patent infringer is 'intimately involved with the substance of the patent laws[,]' the precedent of the Federal Circuit" is determinative (quoting Akro Corp. v. Luker, 45 F.3d 1541, 1543 (Fed. Cir. 1995))); Biometics L.L.C. v. New Womyn, Inc., 112 F. Supp. 2d 869, 871 (E.D. Mo. 2000) ("When deciding an issue of personal jurisdiction in a patent case, a district court must apply law of the Federal Circuit.").

${ }^{197}$ The second prong of the Akro three-prong test, as applied in Rotec, requires a substantive analysis of whether the cause of action for the alleged "offer to sell" arises out of or is related to the in-forum activities that constitute the alleged "offer to sell," as discussed in Part II.C.

${ }^{198}$ Supra notes 33-35 and accompanying text.

${ }^{199}$ See supra note 187 and accompanying text (explaining the distinction between the two parts of a conventional personal jurisdiction inquiry). 
would not be palatable to a court still defining its role less than a quarter of a century after its creation. The more conservative path would be to retain the Akro three-prong framework, but to construe the second prong more liberally as a test of whether the cause of action is "reasonably related to" the activities within the forum.

Under this proposed test, the relationship between the activities, the defendant, and the forum would return to being one of several factors considered in assessing whether personal jurisdiction based on in-forum contacts comports with due process, ${ }^{200}$ instead of the nearly dispositive standard that the current second prong of Akro represents. By using this proposed "reasonably related to" test, the Federal Circuit could attain a conceptual separation between the procedural determination of whether personal jurisdiction is authorized and the substantive determination of the quality of activities captured within the meaning of the statutory "offer to sell" language. Such conceptual separation would bestow the benefit of predictability upon both patentees deciding whether and when to sue and alleged infringers evaluating how to effectively respond to a suit. It would also improve clarity and consistency in the resolution of "offer to sell" infringement cases in the district and Federal Circuit courts.

As a supplement to a more conventional and less rigid personal jurisdiction inquiry, a broader interpretation of "offer to sell" in $\S$ 271(a) would enhance the import of an "offer to sell" infringement cause of action. Expanding the scope of "offer to sell" to include such nascent sales activities as advertising, marketing, and soliciting would better protect a patentee's exclusive right. ${ }^{201}$ Additionally, such an expanded scope would be consistent with the interpretation of "on sale" in $\S 102$ (b), recognizing that the two terms- "offer to sell" in $\S$ 271(a) and "on sale" in $\S 102$ (b) - serve complementary but not identical purposes in patent law. ${ }^{202}$ Even absent a change in the application of the second prong of the Akro three-prong personal jurisdiction inquiry, a more encompassing meaning of "offer to sell" would necessarily expand the range of activities that would satisfy the existing sec-

200 See Int'l Shoe Co. v. Washington, 326 U.S. 310, 319 (1945) ("Whether due process is satisfied must depend rather upon the quality and nature of the activity in relation to the fair and orderly administration of the laws which it was the purpose of the due process clause to insure."); Shaffer v. Heitner, 433 U.S. 186, 204 (1977) (recognizing that "the relationship among the defendant, the forum, and the litigation [is] ... the central concern of the inquiry into personal jurisdiction").

201 See supra notes 100-05 (discussing the economic rationale underlying "offer to sell" infringement).

${ }^{202}$ See supra notes 106-21 (exploring the meaning of "on sale" as defined by Pfaff and the analogy drawn between "on sale" and "offer to sell" in Rotec). 
ond prong, as currently applied, ${ }^{203}$ and would thus strengthen the ability of a patentee to pursue an "offer to sell" infringement action.

\section{CONCLUSION}

Because the prohibition on offering to sell a patented article has been law in the United States for barely more than a decade, ${ }^{204}$ there have been limited opportunities for the concomitant jurisprudence to develop and become refined. ${ }^{205}$ Nevertheless, the doctrine that has emerged from "offer to sell" infringement litigation suffers from two nearly disabling flaws. The primary problem is that the Federal Circuit's three-prong Akro test for specific personal jurisdiction is unnecessarily restrictive in its second prong, requiring that a cause of action arise out of or be (directly) related to the in-forum contacts of the defendant. ${ }^{206}$ Application of the test in "offer to sell" cases has been even more stringent than contemplated by Akro. ${ }^{207}$ As a result, courts applying this test have been drawn into making a substantive determination of whether an "offer to sell" occurred within the meaning of $\S 271$ (a), the patent infringement statute, in order to decide a preliminary procedural motion to dismiss for lack of personal jurisdiction.

The secondary problem is that the Federal Circuit's substantive determination of the meaning of "offer to sell" under $\S 271$ (a) fails to cover most of the widely ranging pre-sale activities that detract from the economic value of a patentee's grant of exclusivity. ${ }^{208}$ By construing "offer to sell" to be equivalent to the "on sale" bar of $\S 102$ (b) ${ }^{209}$ and the "offer" in traditional contract law, the ban on "offer to sell" activities is reduced to serving as a tool that merely enables a patentee

${ }^{203}$ See supra Part I.B for an analysis of the Federal Circuit's application of the Akro three-prong test in "offer to sell" infringement cases.

${ }^{204}$ See supra note 2 (describing the 1994 modification of U.S. law that included the addition of the "offer to sell" language to $§ 271(\mathrm{a})$ ).

${ }^{205}$ There have been no Supreme Court cases on "offer to sell" infringement and only five such Federal Circuit cases: Fieldturf Int'l, Inc. v. Sprinturf, Inc., 433 F.3d 1366 (Fed. Cir. 2006); MEMC Elec. Materials, Inc. v. Mitsubishi Materials Silicon Corp., 420 F.3d 1369 (Fed. Cir. 2005); Rotec Indus., Inc. v. Mitsubishi Corp., 215 F.3d 1246 (Fed. Cir. 2000); HollyAnne Corp. v. TFT, Inc., 199 F.3d 1304 (Fed. Cir. 1999); and 3D Sys., Inc. v. Aarotech Lab., Inc., 160 F.3d 1373 (Fed. Cir. 1998).

${ }^{206}$ See supra notes 33-35 and accompanying text.

${ }^{207}$ See supra notes 67, 79 and accompanying text (discussing the impact of stiffening the "related to" branch of the second prong in the Akro personal jurisdiction test).

${ }^{208}$ See supra notes 96, 100-04 and accompanying text (arguing for a broader construction of the meaning of "offer").

${ }^{209}$ See supra Part II.B (discussing the definition of an offer under the "on sale" bar). 
to bring suit at a slightly earlier time, and only in cases where an actual infringing sale later occurs or is contemplated to occur. ${ }^{210}$

For there to be a viable and enforceable cause of action for "offer to sell" infringement, this Comment proposes that the Federal Circuit should more liberally construe the second prong of $A k r o^{211}$ so that a cause of action reasonably related to the defendant's in-forum activities would suffice to convey personal jurisdiction, bounded by the requirements of due process. This critical conceptual separation between "offer to sell" activities adequate to justify the exercise of personal jurisdiction and "offer to sell" activities satisfying the meaning of the statutory term in $\S 271$ (a) would both stabilize the Akro test and give the Federal Circuit more opportunities to flesh out the substantive meaning of "offer to sell.",

Additionally, this Comment proposes that the Federal Circuit interpret "offer to sell" to include pre-sale activities such as advertising, marketing, and soliciting that sufficiently describe the article offered and the terms of the offer to cause the market for the patented article to be negatively impacted, even if such pre-sale activities fall short of the technical requirements of a potentially contractually binding offer. ${ }^{213}$

In sum, the addition of "offer to sell" language to the patent infringement statute, $\S 271(\mathrm{a})$, created an opportunity for the federal courts to enhance protection of the exclusive rights granted to patentees in order to promote the advancement of science for the benefit of all. ${ }^{214}$ If the doctrine and statutory language are to fulfill that mandate, the Federal Circuit must first enunciate a clear standard by which it will assert personal jurisdiction over defendants in "offer to sell" patent infringement cases and must then set forth an interpretation of the term "offer to sell" which effectively protects the grant to the patentee over the life of the patent.

${ }^{210}$ See supra notes 96, 103 and accompanying text (criticizing the limitations imposed by the narrowest interpretation of the term "offer to sell").

${ }^{211}$ See supra note 34 and accompanying text (setting forth the second Akro prong).

${ }^{212}$ If the district courts are permitted to take jurisdiction over more cases, presumably more will reach the CAFC on appeal.

${ }^{213}$ See FARNSWORTH, supra note 48, § 3.3, at 112-13 (defining an offer under contract law).

${ }^{214}$ U.S. CONST. art. I, § 8, cl. 8. 